\title{
Impacts of controlled forest fires on soil properties in Gadchiroli Forest Circle, Central India
}

\section{Impactos de los incendios forestales controlados en las propiedades del suelo en Gadchiroli Forest Circle, India central}

\author{
Rahul K. Kamble \\ Centre for Higher Learning and Research in Environmental Science \\ Sardar Patel College, Ganj Ward, Chandrapur 442 402, India \\ Author for Correspondence: +91 9665499330, rahulkk41279@yahoo.com
}

\begin{abstract}
Forest is an important ecosystem service to human beings. In recent decades the forest is facing tremendous pressure from anthropogenic activities. One of the activities is the burning of forest floor for easy collection of non-timber forest produce. As a result of this number of incidences of forest fires has increased in the tribal-dominated area of the world. These forest fires have adverse impacts on soil properties which will ultimately in the long term have impacts on the forest ecosystem. Taking into consideration this fact this study was attempted to assess the impacts of controlled forest fires on the physicochemical properties of forest soil in the Gadchiroli forest circle of Central India. To assess the impacts six sampling sites from the forest where identified from the study area where no previous forest fire history was recorded in that season. Initial soil sampling before controlled forest fire was carried out in summer 2019 by quartering method in the topsoil layer $(1-5 \mathrm{~cm})$. A controlled forest fire was carried out in the same area. The soil was prepared for soil analysis and analysed by adopting standard methods for bulk density, water holding capacity, $\mathrm{pH}$, electrical conductivity, organic carbon, and organic matter. Results revealed that forest fires increase the bulk density of soil, at $50 \%(n=3)$ sampling locations water holding capacity got reduced down; whereas, at other half increased in capacity was observed. In the case of soil pH $66 \%(n=4)$ sample reported increased in soil $\mathrm{pH}$ and at other reduction in soil $\mathrm{pH}$ was recorded. Except at one sampling location electrical conductivity was reduced. A similar trend was also noticed for organic carbon and organic matter. Bulk density and water holding capacity will have long term impacts; whereas, $\mathrm{pH}$, electrical conductivity, organic carbon and organic matter will have short term impacts. Furthermore, in those sampling locations where forest fire does not occur in the last 2-3 years organic carbon and organic matter content of the soil is high. Thus,
\end{abstract}


Sustainability, Agri, Food and Environmental Research, (ISSN: 0719-3726), X(X), 2021: 231-262 http://dx.doi.org/10.7770/safer-V0NO-art2253

measures to be taken to reduce forest fires activities by incorporating an effective forest fire management system at a place by incorporating fire load management subsystem and fire suppression subsystem.

Keywords: forest fire, forest floor, soil quality, Gadchiroli, Central India

\section{RESUMEN}

El bosque es un servicio ecosistémico importante para los seres humanos. En las últimas décadas, el bosque se enfrenta a una tremenda presión por las actividades antropogénicas. Una de las actividades es la quema del suelo del bosque para facilitar la recolección de productos forestales no maderables. Como resultado de este número de incidentes de incendios forestales ha aumentado en el área del mundo dominada por tribus. Estos incendios forestales tienen impactos adversos en las propiedades del suelo que, en última instancia, tendrán impactos a largo plazo en el ecosistema forestal. Teniendo en cuenta este hecho, este estudio se intentó evaluar los impactos de los incendios forestales controlados en las propiedades fisicoquímicas del suelo forestal en el círculo forestal de Gadchiroli en la India central. Para evaluar los impactos, se identificaron seis sitios de muestreo del bosque en el área de estudio donde no se registró ningún historial de incendios forestales en esa temporada. El muestreo inicial del suelo antes del incendio forestal controlado se realizó en el verano de 2019 mediante el método de cuarteo en la capa superior del suelo $(1-5 \mathrm{~cm})$. En la misma zona se llevó a cabo un incendio forestal controlado. El suelo se preparó para el análisis del suelo y se analizó mediante la adopción de métodos estándar de densidad aparente, capacidad de retención de agua, pH, conductividad eléctrica, carbono orgánico y materia orgánica. Los resultados revelaron que los incendios forestales aumentan la densidad aparente del suelo, en un $50 \%(n=3)$, la capacidad de retención de agua de los lugares de muestreo se redujo; mientras que en la otra mitad se observó un aumento de capacidad. En el caso del pH del suelo $66 \%(n=4)$, la muestra reportó un aumento en el $\mathrm{pH}$ del suelo y en otros casos se registró una reducción en el pH del suelo. Excepto en un lugar de muestreo, se redujo la conductividad eléctrica. También se observó una tendencia similar para el carbono orgánico y la materia orgánica. La densidad aparente y la capacidad de retención de agua tendrán impactos a largo plazo; mientras que el $\mathrm{pH}$, la conductividad eléctrica, el carbono orgánico y la materia orgánica tendrán impactos a corto plazo. Además, en los lugares de muestreo donde no se producen incendios forestales en los últimos 2-3 años, el contenido de carbono orgánico y materia orgánica del suelo es alto. Por lo tanto, se deben tomar medidas para reducir las actividades de incendios forestales mediante la incorporación de un sistema de manejo de incendios forestales efectivo en un lugar mediante la incorporación de un subsistema de manejo de carga de incendios y un subsistema de extinción de incendios. 
Sustainability, Agri, Food and Environmental Research, (ISSN: 0719-3726), X(X), 2021: 231-262 http://dx.doi.org/10.7770/safer-VONO-art2253

Palabras clave: incendio forestal, suelo forestal, calidad del suelo, Gadchiroli, India central

\section{INTRODUCTION}

Man's relationship with fire dates back into pre-history. A forest fire has emerged as a major disaster in our environment in recent decades. Anthropogenic activities are major reasons for forest fires especially for the collection of non-timber forest produce viz. tendu (Diospyros melanoxylon) leaves and moha (Madhuca longifolia) flowers. According to the Food and Agricultural Organization (FAO) (2015), an average of about 67 million hectares or $1.7 \%$ of forest land is burned each year in the world (Table 1 ).

Table 1: Land and forest areas burned globally

\begin{tabular}{lllllll}
\hline Year & $\begin{array}{l}\text { Burned land } \\
\text { (000 ha) }\end{array}$ & $\begin{array}{l}\text { \% of land } \\
\text { burned }\end{array}$ & $\begin{array}{l}\text { Burned forest } \\
\text { (000 ha) }\end{array}$ & $\begin{array}{l}\text { Burned forest as } \\
\text { \% of burned land }\end{array}$ & $\begin{array}{l}\text { Total forest } \\
\text { (000 ha) })\end{array}$ & $\begin{array}{l}\text { \% of total } \\
\text { forest } \\
\text { burned }\end{array}$ \\
\hline 2003 & 355300 & 2.8 & 68592 & 19.3 & 4042531 & 1.7 \\
2004 & 384798 & 3.0 & 75636 & 19.7 & 4038801 & 1.9 \\
2005 & 369817 & 2.9 & 78497 & 21.2 & 4035072 & 1.9 \\
2006 & 337990 & 2.6 & 64250 & 19.0 & 4031342 & 1.6 \\
2007 & 381897 & 3.0 & 84965 & 22.2 & 4027613 & 2.1 \\
2008 & 322705 & 2.5 & 56820 & 17.6 & 4023883 & 1.4 \\
2009 & 308935 & 2.4 & 53728 & 17.4 & 4020154 & 1.3 \\
2010 & 325229 & 2.5 & 65225 & 20.1 & 4016424 & 1.6 \\
2011 & 322228 & 2.5 & 55479 & 17.2 & 4012695 & 1.4 \\
2012 & 297137 & 2.3 & 63141 & 21.2 & 4008965 & 1.6 \\
\hline
\end{tabular}

Note: Total land area for all years: 12908461 (000 ha). It should be noted that in the case of repeated fires in the same area, it has been accounted for each time.

In India, about $2-3 \%$ of the forest area is affected annually by fire and an average 34,000 hectares of forest area is burnt by fire each year. The Gadchiroli forest circle has emerged as the top district with forest fire incidences. Table 2 presents the top 20 districts 
of India in terms of area affected by forest fire from 2003 to 2016 account for $48 \%$ of the total fire-affected area.

Table 2: Top 20 districts by the total area affected by fire, 2003-2016

\begin{tabular}{|c|c|c|c|c|}
\hline No. & District, State, Region & $\begin{array}{l}\text { Fire affected } \\
\text { area, } 2003- \\
2016(\mathrm{sq} \mathrm{km})\end{array}$ & $\begin{array}{l}\text { Share of burnt } \\
\text { area, } \\
2003-2016(\%)\end{array}$ & $\begin{array}{l}\text { Share of total } \\
\text { forest cover, } \\
2000(\%)\end{array}$ \\
\hline 1. & Gadchiroli, Maharashtra, C & 4,106 & 8.24 & 1.56 \\
\hline 2. & Bijapur, Chhattisgarh, C & 2,633 & 5.29 & 1.19 \\
\hline 3. & Khammam, Telangana, S & 1,923 & 3.86 & 1.13 \\
\hline 4. & $\begin{array}{l}\text { Narayanpur, Chhattisgarh, } \\
\text { C }\end{array}$ & 1,346 & 2.70 & 0.78 \\
\hline 5. & Warangal, Telangana, S & 1,273 & 2.56 & 0.45 \\
\hline 6. & Koriya, Chhattisgarh, C & 1,169 & 2.35 & 0.42 \\
\hline 7. & Adilabad, Telangana, S & 995 & 2.00 & 0.39 \\
\hline 8. & Chandrapur, Maharashtra, C & 970 & 1.95 & 0.31 \\
\hline 9. & Surguja, Chhattisgarh, C & 948 & 1.90 & 0.79 \\
\hline 10. & Kurnool, Andhra Pradesh, S & 895 & 1.80 & 0.23 \\
\hline 11. & Amravati, Maharashtra, C & 888 & 1.78 & 0.23 \\
\hline 12. & Y.S.R., Andhra Pradesh, S & 854 & 1.71 & 0.32 \\
\hline 13. & Prakasam, Andhra Pradesh, S & 849 & 1.70 & 0.31 \\
\hline 14. & $\begin{array}{l}\text { Dakshin Bastar Dantewada, } \\
\text { Chhattisgarh, C }\end{array}$ & 803 & 1.61 & 0.73 \\
\hline 15. & Bilaspur, Chhattisgarh, C & 799 & 1.60 & 0.36 \\
\hline 16. & Raipur, Chhattisgarh, C & 777 & 1.56 & 0.50 \\
\hline 17. & Betul, Madhya Pradesh, C & 727 & 1.46 & 0.29 \\
\hline 18. & Champhai, Mizoram, NE & 707 & 1.42 & 0.64 \\
\hline 19. & Lawngtlai, Mizoram, NE & 673 & 1.35 & 0.43 \\
\hline 20. & Dima Hasao, Assam, NE & 665 & 1.34 & 0.91 \\
\hline
\end{tabular}

Notes: $\mathrm{C}=$ Central; NE = Northeast; $\mathrm{S}=$ South

(Data source: MODIS monthly data product for active fires (MCD14ML), provided by Forest Survey of India; MODIS monthly data product for the burnt area (MCD45A1); forest cover data for 2000 from Hansen et al. (2013); district boundaries as of 2012).

The major cause of vegetation forest in India is man-made (Srivastava and Garg, 2013). The soil has a very complex effect of prescribed fire on the forest. Effects can be observed on soil organic matter, macro and micronutrients, $\mathrm{pH}$, bulk density, soil texture, colour and soil biota (Verma and Jayakumar, 2012). Burning induced water repellency in the soil is reported by DeBano and Krammes, 1966; Savage, 1974; DeBano, 1996. 
Increase in soil pH by 4 or 5 units after the high-intensity fire due to the reduction of soil organic matter (Ulery et al., 1995). DeBano et al., 1977; Carballas, 1993; Kutiel and Inbar, 1993; Hernandez et al., 1997 observed increase in soil electrical conductivity after the incorporation of soluble salts released by the combustion of organic matter. Organic carbon content may increase after low-intensity fires due to partially pyrolyzed plant residue; whereas, a decrease in organic carbon content in medium or high-intensity fires (MataixSolera et al., 2002). Upper horizons of soil profile have serious changes (Maksimova and Abakumov, 2014). Soil initial characteristics decide the effects on soil properties in a prescribed fire (Alcaniz et al., 2018). Rastad (2009); Arocena and Opio (2003) reported important changes in physical and chemical properties of forest soils viz. bulk density and altered physical structures. According to Badia and Marti (2003) C:N ratio, soil organic matter content, and nutrient availability all increased after burning. After carrying out a literature review it is observed that there is no study on the impacts of forest fire on forest floors' physical and chemical characteristics in the Gadchiroli forest circle of Central India. thus, this study was proposed to carry out with objectives i) to assess the impacts of forest fire on soils physical properties viz. moisture, bulk density, and water holding capacity and ii) to assess the impacts of forest fire on soils chemical properties viz. $\mathrm{pH}$, electrical conductivity, organic carbon and organic matter.

\section{MATERIAL AND METHODOLOGY}

Study area: Gadchiroli district lies between $19^{\circ} 00^{\prime}$ and $21^{\circ} 00^{\prime}$ North latitude and $80^{\circ} 00^{\prime}$ and $81^{\circ} 00^{\prime}$ East longitude (Figure 1 ). It is surrounded by Bhandara district in north, Rajnandgaon and Bastar districts of Chhattisgarh in the east, Karimnagar and Adilabad districts of Telangana in the south, and Chandrapur district in the west. The district is spread over an area of $14412.00 \mathrm{sq} \mathrm{km}$ constituting 4.68 percent of the total area of the Maharashtra state and has a population of 10,72,942 (Census of India, 2011).

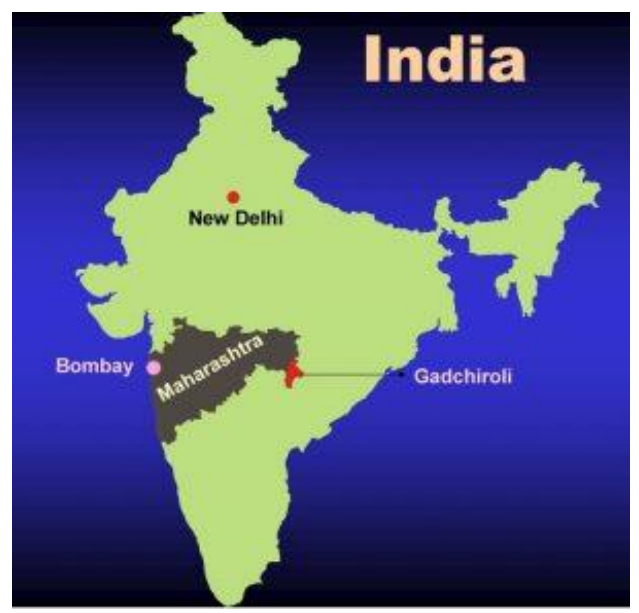

Figure 1: Study area 
Climate: The climate of the district is dry and salubrious. It is characterised by hot summer, well-distributed rainfall during the south-west monsoon season and generally dryness except in the rainy season. Meteorological data are available for eight stations viz., Gadchiroli, Armori, Kurkheda, Dhanora, Chamorshi, Sironcha, Aheri, and Alapalli. The rainy season generally starts in June and lasts up to October. It is followed by a cold season from November to February and the hot season from March to May.

This is one of the hottest districts in Maharashtra. After October both day and night temperatures decreases progressively till December which is the coldest month. During the cold season, cold spell affects the district in association with the passage of western disturbances across north India. Among the four towns of the district, Gadchiroli, Alapalli, and Aheri have reported $46.3^{\circ} \mathrm{C}$ as the maximum temperature and $12.7^{\circ} \mathrm{C}$ as the minimum temperature. In the district, Sironcha recorded the highest maximum temperature of $47.1^{\circ} \mathrm{C}$ in 1980 and the lowest minimum temperature of $7.8^{\circ} \mathrm{C}$ in 1951 (Census of India, 2001).

Land use pattern: The land use pattern of the district is presented in Table 3. From the table, it can be seen that the forest area is the major (75.93\%) area of the district; whereas, the cultivable area is $15.75 \%$.

Table 3: Land use pattern of the district

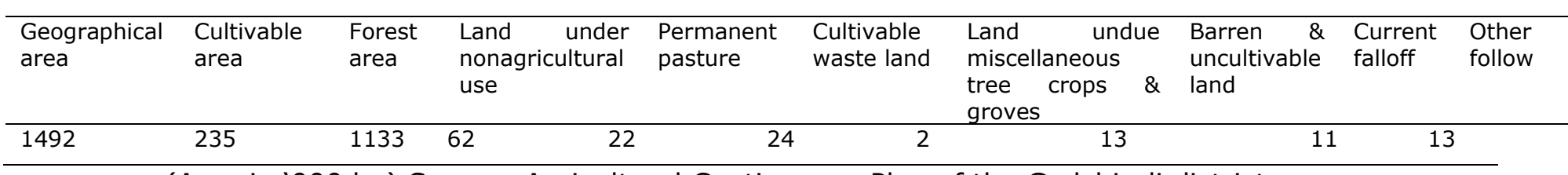

(Area in '000 ha) Source: Agricultural Contingency Plan of the Gadchiroli district

Forest from the study area: Table 4 presents the Gadchiroli circle and district distribution of forest area in charge of the Forest Department and Revenue Department as of 2016-17. From the table, it can be seen that maximum reserved forests ( $9874.32 \mathrm{sq}$ $\mathrm{km}$ ) are controlled by Forest (Terri.) followed by protected forests (1360.04 sq km). The forest area controlled by FDCM is $681.49 \mathrm{sq} \mathrm{km}$ of reserves forests.

Table 4: Gadchiroli circle and district distribution of forest area (2016-17)

\begin{tabular}{lllll}
\hline Controlling agency & Reserved forests & Protected forests & Un-classed forests & Total forests \\
\hline Forest (Terri) & 9874.32 & 1360.04 & 42.11 & 11276.47 \\
Wildlife & 830.99 & 7.75 & 0 & 838.74 \\
FDCM & 681.49 & 29.80 & 0 & 711.29 \\
Revenue & 0 & 0 & 18.53 & 18.53 \\
\hline Total & 11386.8 & 1397.59 & 60.64 & 12845.03 \\
\hline
\end{tabular}

Source: Annual Administration Report, 2016-17 (Area in sq km) 
The forest cover of the Gadchiroli district is presented in Table 5. The forests cover according to the area is in the order of very dense $>$ moderately dense $>$ open forest $>$ scrub. Of the total geographical area of the district, very dense forest contributes $32.81 \%$; whereas, moderately dense $23.44 \%$. Very dense and moderately dense forest together contributes $56.26 \%$. In the case of the open forest, it covers only $13.79 \%$, where scrub covers the least $(0.13 \%)$.

Table 5: Gadchiroli district forest cover

\begin{tabular}{lllllll}
\hline $\begin{array}{l}\text { Geographical } \\
\text { area }\end{array}$ & \multicolumn{5}{c}{ Forest cover 2015 } \\
\cline { 2 - 6 } & Very dense & Moderately dense & Total & Open forest & Total & Scrub \\
\hline 14412 & 4730 & 3379 & 8109 & 1988 & 10097 & 20 \\
\hline
\end{tabular}

Source: Annual Administration Report, 2016-17 (Area in sq km)

Administrative blocks having forest (in percentage) area are presented in Table 6. From the table it can be seen that Etapalli has a minimum (50.34\%) forest area; whereas, Kurkheda has a maximum (93.17\%).

Table 6: Administrative blocks having forest area

\begin{tabular}{ll}
\hline Administrative block & Forest area (\%) \\
\hline Kurkheda & 93.17 \\
Armori & 91.53 \\
Gadchiroli & 80.95 \\
Chamorshi & 79.28 \\
Dhanora & 72.31 \\
Aheri & 71.88 \\
Sironcha & 65.79 \\
Etapalli & 50.34 \\
\hline
\end{tabular}

Source: Census of India, 2001

Details about range, round, and beat of the Gadchiroli forest circle (2016-17) are presented in Table 7. From the table, it can be seen that 736 beats are there for 12845.03 sq km forest area thus one beat covers an approximate area of $17.45 \mathrm{sq} \mathrm{km}$.

Outturn and value of important minor forest produce in Maharashtra collected during the year 2016-17 is given in Table 8 . In the table selected minor forest produce is presented. It can be seen that revenue collected from these produce (2016-17) is in the order of tendu and apta leaves > bamboo > moha flowers, moha fruits, and seeds.

Table 7: Range, round and beat of Gadchiroli forest circle

\begin{tabular}{lllll}
\hline Division Sub-division & Total No. of ranges & No. of rounds & No. of beats
\end{tabular}


Sustainability, Agri, Food and Environmental Research, (ISSN: 0719-3726), X(X), 2021: 231-262 http://dx.doi.org/10.7770/safer-VONO-art2253

\begin{tabular}{llllll}
\hline 5 & 0 & 5 & 37 & 166 & 736 \\
\hline
\end{tabular}

Source: Annual Administration Report, 2016-17

Table 8: Outturn and value of minor forest produce in Maharashtra

\begin{tabular}{llllll}
\hline Item & Unit & \multicolumn{2}{c}{ Quantity (Approx.) } & \multicolumn{2}{c}{ Value (Rs. in Lakh) } \\
\cline { 3 - 6 } & & $2016-17$ & $2015-16$ & $2016-17$ & $2015-16$ \\
\hline Bamboo & M.T. & 10603 & 8773 & 999.18 & 769.62 \\
Tendu \& Apta leaves & Std. Bag & 285598 & 458087 & 5473.20 & 6457.36 \\
Moha flowers, moha & Qtl. & 7986.348 & 9860 & 157.91 & 179.13 \\
fruits and seeds & & & & & \\
\hline
\end{tabular}

Source: Annual Administration Report, 2016-17

Sampling sites: To assess the impacts of controlled forest fire on the physicochemical properties of soil from the Gadchiroli district six administrative blocks were identified. The identified sites with the description of the sampling locations about geographical details, soil type, vegetation present, litter biomass description and previous history of forest fire are presented in Table 9.

Only those areas were selected for the study where no forest fire incident took place in that season or previous years to assess the impacts of controlled forest fires on soil properties. The study was carried out in the summer 2019. The sampling plot from each administrative block of about one acre in size in the forest was selected. Also, it should be representative of the forest area from that sampling area.

Before carrying out the controlled forest fire study from the study area, baseline environmental conditions were assessed concerning atmospheric relative humidity, soil moisture, tree biodiversity, leaf litterfall its composition and status. Trees and understory vegetation from the area were also noted down. Soil type and previous history of forest fire incidences were also collected from the Range Forest Officer of the respective area. 
Sustainability, Agri, Food and Environmental Research, (ISSN: 0719-3726), X(X), 2021: 231-262

http://dx.doi.org/10.7770/safer-V0N0-art2253

Table 9: Forest fire sampling locations details

\begin{tabular}{|c|c|c|c|c|c|c|c|}
\hline \multirow{2}{*}{$\begin{array}{l}\text { Sampling } \\
\text { location } \\
\text { (Forest type) }\end{array}$} & \multirow{2}{*}{$\begin{array}{l}\text { Administra } \\
\text { tive block }\end{array}$} & \multicolumn{2}{|c|}{ Geographical details } & \multirow[t]{2}{*}{ Soil type } & \multirow[t]{2}{*}{ Vegetation present } & \multirow{2}{*}{$\begin{array}{l}\text { Litter biomass } \\
\text { details }\end{array}$} & \multirow{2}{*}{$\begin{array}{l}\text { Previous history of } \\
\text { forest fires }\end{array}$} \\
\hline & & $\begin{array}{l}\text { Latitude } \\
\text { Longitude }\end{array}$ & $\begin{array}{l}\text { Altitude } \\
\text { (m, asl) }\end{array}$ & & & & \\
\hline $\begin{array}{l}\text { Kothari bit, } \\
330 \text { (Reserved } \\
\text { forest) }\end{array}$ & Mulchera & $\begin{array}{l}79^{\circ} 57^{\prime} 31^{\prime \prime} \mathrm{E} \\
19^{\circ} 34^{\prime} 09^{\prime \prime} \mathrm{N}\end{array}$ & 181 & Sand mix & $\begin{array}{l}\text { Mix type; Teak, Palas, Yen, } \\
\text { Kalam }\end{array}$ & $\begin{array}{l}\text { Dried leaves of } \\
\text { teak and palas }\end{array}$ & $\begin{array}{l}\text { No history of forest } \\
\text { fire in the season }\end{array}$ \\
\hline $\begin{array}{l}\text { Ghot } 1,850 \\
\text { (Reserved } \\
\text { forest) }\end{array}$ & Chamorshi & $\begin{array}{l}79^{\circ} 58^{\prime} 48^{\prime \prime} \mathrm{E} \\
19^{\circ} 48^{\prime} 39^{\prime \prime} \mathrm{N}\end{array}$ & 249 & $\begin{array}{l}\text { Sand mix } \\
\text { white type }\end{array}$ & $\begin{array}{l}\text { Mix type; Yen, Rovan, Palas, } \\
\text { Khair, Bija, Moha, Neem, } \\
\text { Tendu; small shrubs }\end{array}$ & $\begin{array}{l}\text { Dried leaves of } \\
\text { vegetation } \\
\text { present along } \\
\text { with some twigs }\end{array}$ & $\begin{array}{l}\text { No history of forest } \\
\text { fire in the season }\end{array}$ \\
\hline $\begin{array}{l}\text { Jamgiri bit, } \\
363 \text { (Reserved } \\
\text { forest) }\end{array}$ & Chamorshi & $\begin{array}{l}79^{\circ} 52^{\prime} 09^{\prime \prime} \mathrm{E} \\
19^{\circ} 51^{\prime} 05^{\prime \prime} \mathrm{N}\end{array}$ & 183 & Black soil & $\begin{array}{l}\text { Mix type; Yen, Dhawada, Palas, } \\
\text { Mowai, Tendu, Khair, Neem, } \\
\text { Hiwar, Shatawari, Bhuineem, } \\
\text { Sindhi }\end{array}$ & $\begin{array}{l}\text { Dried leaves of } \\
\text { vegetation } \\
\text { present in the } \\
\text { area }\end{array}$ & $\begin{array}{l}\text { No history of forest } \\
\text { fire in the season }\end{array}$ \\
\hline $\begin{array}{l}\text { Talwada } 2 \text { bit, } \\
\text { compartment } \\
\text { no. } 61 \\
\text { (Reserved } \\
\text { forest) }\end{array}$ & Aheri & $\begin{array}{l}80^{\circ} 08^{\prime} 57^{\prime \prime} \mathrm{E} \\
19^{\circ} 21^{\prime} 49^{\prime \prime} \mathrm{N}\end{array}$ & 238 & $\begin{array}{l}\text { Sandy soil } \\
\text { and small } \\
\text { rocks were } \\
\text { present }\end{array}$ & $\begin{array}{l}\text { Teak, Apata, Bamboo, Tendu, } \\
\text { Garadi, Surya, Lendi, Kusum, } \\
\text { Moha, Sesam. Herbs and shrubs } \\
\text { not present to that extend }\end{array}$ & $\begin{array}{l}\text { Dried leaves of } \\
\text { teak, kusum, } \\
\text { apate and tendu. } \\
\text { Palas leaves } \\
\text { flown away from } \\
\text { other areas. }\end{array}$ & $\begin{array}{l}\text { No history of forest } \\
\text { fire in the season }\end{array}$ \\
\hline $\begin{array}{l}\text { Kondhala, } \\
\text { Compartment } \\
\text { no. } 58\end{array}$ & Wadsa & $\begin{array}{l}79^{\circ} 59^{\prime} 35^{\prime \prime} \mathrm{E} \\
20^{\circ} 31^{\prime} 19^{\prime \prime} \mathrm{N}\end{array}$ & 206 & $\begin{array}{l}\text { Sand mix } \\
\text { black soil }\end{array}$ & $\begin{array}{l}\text { Teak, Yen, Behead, Tendu, } \\
\text { Garadi, Yeroni, Kukudranji, }\end{array}$ & $\begin{array}{l}\text { Dried leaves of } \\
\text { teak, dhawada, }\end{array}$ & $\begin{array}{l}\text { Since last three } \\
\text { years no forest fires } \\
\text { in this area }\end{array}$ \\
\hline
\end{tabular}


Sustainability, Agri, Food and Environmental Research, (ISSN: 0719-3726), X(X), 2021: 231-262 http://dx.doi.org/10.7770/safer-V0NO-art2253

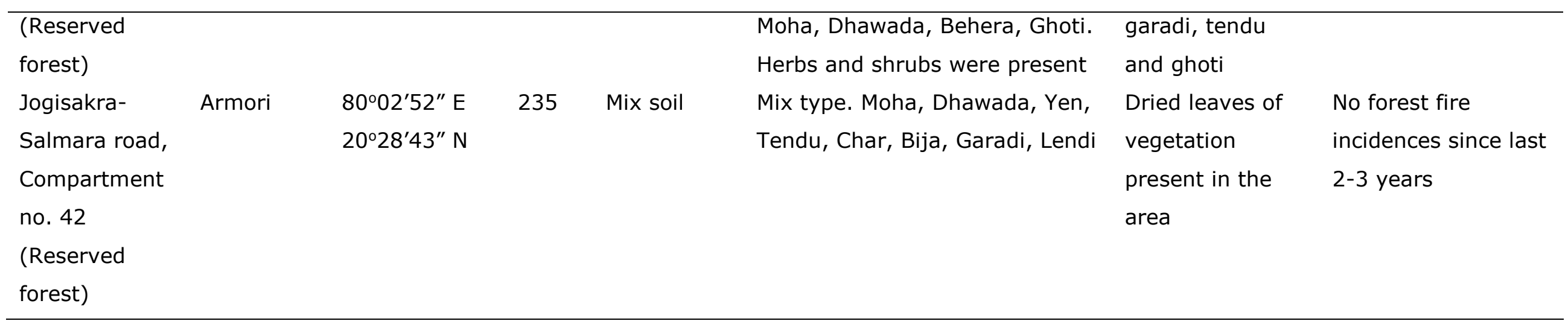


Sustainability, Agri, Food and Environmental Research, (ISSN: 0719-3726), X(X), 2021: 231-262 http://dx.doi.org/10.7770/safer-VONO-art2253

Before starting the fire, a fire line was demarcated in the identified area so as the fire will be in control and it will be spread in a confined area only. The forest fire study was carried out in the morning hours ( 8.30 am to 12 noon). To know the precise location of the study area, a handheld GPS (Map my India navigation 2.0) was used to record the geographical location of the study site viz. latitude, longitude, and altitude. Atmospheric ambient temperature was recorded with the help of a mercury thermometer; whereas, atmospheric humidity with the help of a psychrometer (Dimple sling psychrometer, India). Photographs were taken from the sampling locations to compare them after forest fire study.

Soil sampling: Soil sampling was carried out to assess the impacts of controlled forest fire on its physical and chemical properties. Soil sampling from the identified location was carried out by quartering method. From each sampling location, soil samples were collected before and after a controlled forest fire study. While carrying out the soil sampling leaf litter from the identified area was removed and soil sampling at a depth of $0-10 \mathrm{~cm}$ was carried out by the ' $\mathrm{V}$ ' notch method. For carrying out a ' $\mathrm{V}$ ' notch spade was used. Approximately $1000 \mathrm{~g}$ of soil sample was collected from each spot in a clean plastic container and five such soil samples from the identified area in a crisscross manner were collected to have a representative soil sample. In a similar manner after controlled forest fire samples were collected from the identified location. A composite sample was made on a clean plastic sheet. The collected soil sample was then subjected to the quartering method and a sample was derived from it for its analysis. While carrying out the quartering method stones and roots of plants and trees were removed. The derived sample was set aside in double polythene bags. The soil sample bag was properly sealed and labelled for identification. The details about the same were also noted down in the field diary. While carrying out the soil sampling the exposed roots and other observations were recorded. The collected soil samples before and after controlled forest fire were brought to the laboratory of the Department of Environmental Science, Sardar Patel College, Chandrapur for its further physicochemical analysis.

Controlled forest fire: The litter biomass from the identified sampling locations was assessed. Before setting it to fire, wind blowing direction was assessed and the fire was set in that direction only. After setting the leaf litter to fire its progress in the forest was noted. While controlled forest fire in progress its nature about the type of forest fire, type of fire intensity, flame description, presence of smoke and litter status after forest fire was recorded (Table 10). 
Sustainability, Agri, Food and Environmental Research, (ISSN: 0719-3726), X(X), 2021: 231-262

http://dx.doi.org/10.7770/safer-VONO-art2253

Table 10: Fuel and flame characteristics

\begin{tabular}{|c|c|c|c|c|c|c|c|c|}
\hline Sampling location & Fuel description & $\begin{array}{l}\text { Fuel } \\
\text { status }\end{array}$ & $\begin{array}{l}\text { Fuel } \\
\text { classificationt }\end{array}$ & $\begin{array}{l}\text { Type of } \\
\text { forest } \\
\text { fire§ }\end{array}$ & $\begin{array}{l}\text { Type of } \\
\text { fire } \\
\text { intensity* }\end{array}$ & $\begin{array}{l}\text { Flame } \\
\text { height }\end{array}$ & $\begin{array}{l}\text { Presen } \\
\text { ce of } \\
\text { smoke }\end{array}$ & $\begin{array}{l}\text { Litter status after } \\
\text { forest fire }\end{array}$ \\
\hline Kothari bit, 330 & Leaves of teak and palas & Dried & Ground & Surface & Low & Low & No & $\begin{array}{l}\text { Litter completely } \\
\text { burnt }\end{array}$ \\
\hline Ghot 1, 850 & $\begin{array}{l}\text { Leaves of vegetation present } \\
\text { along with few twigs }\end{array}$ & Dried & Ground & Surface & Low & Low & No & $\begin{array}{l}\text { Litter completely } \\
\text { burnt }\end{array}$ \\
\hline Jamgiri bit, 363 & $\begin{array}{l}\text { Leaves of vegetation present } \\
\text { in the area }\end{array}$ & Dried & Ground & Surface & Low & Low & No & $\begin{array}{l}\text { Litter completely } \\
\text { burnt }\end{array}$ \\
\hline $\begin{array}{l}\text { Talwada } 2 \text { bit, } \\
\text { compartment no. } \\
61\end{array}$ & $\begin{array}{l}\text { Leaves of teak, kusum, } \\
\text { apate and Tendu. Palas } \\
\text { leaves flown away from } \\
\text { other areas. }\end{array}$ & Dried & Ground & Surface & Low & Low & No & $\begin{array}{l}\text { Litter completely } \\
\text { burnt }\end{array}$ \\
\hline $\begin{array}{l}\text { Kondhala, } \\
\text { compartment no. } \\
58\end{array}$ & $\begin{array}{l}\text { Leaves of Teak, Dhawada, } \\
\text { Garadi, Tendu and Ghoti }\end{array}$ & Dried & Ground & Surface & Low & Low & No & $\begin{array}{l}\text { Litter completely } \\
\text { burnt }\end{array}$ \\
\hline $\begin{array}{l}\text { Jogisakra-Salmara } \\
\text { road, compartment } \\
\text { no. } 42\end{array}$ & $\begin{array}{l}\text { Leaves of Moha, Dhawada, } \\
\text { Yen, Tendu along with dried } \\
\text { tree twigs }\end{array}$ & Dried & Ground & Surface & Low & Medium & Yes & $\begin{array}{l}\text { Litter completely } \\
\text { burnt, except } \\
\text { tree twigs }\end{array}$ \\
\hline
\end{tabular}

†Ground, surface and crown. §Ground, surface and crown. *Low, medium, high. 
Sustainability, Agri, Food and Environmental Research, (ISSN: 0719-3726), X(X), 2021: 231-262 http://dx.doi.org/10.7770/safer-VONO-art2253

After the complete burning of leaf litter biomass by a controlled forest fire from the identified sampling location after a gap of 30-minute soil sampling was again carried out in the same manner from the same area to ascertain the impacts of controlled forest fire on soil's physicochemical properties. While collecting after forest fire samples the top burned leaf litter was removed and soil sampling by quartering method was carried out. Thus, from an identified sampling location before and after controlled forest fire samples were collected. The characteristics of the study site and determinant factors of fire severity are presented in Table 11.

Table 11: Characteristics of study sites and determinant factors of fire severity

\begin{tabular}{|c|c|c|c|c|c|}
\hline \multirow[t]{2}{*}{ Sampling location } & \multicolumn{3}{|c|}{ Physiographic factors } & \multirow{2}{*}{$\begin{array}{l}\text { Canopy } \\
\text { cover }(\%)\end{array}$} & \multirow{2}{*}{$\begin{array}{c}\text { Duration of } \\
\text { combustion (minutes) }\end{array}$} \\
\hline & Altitude $(\mathrm{m}$, asl $)$ & Aspect & Slope (\%) & & \\
\hline Kothari bit, 330 & 181 & Flat & $0 \%$ & $50-70 \%$ & 20 \\
\hline Ghot 1, 850 & 249 & Flat & $0 \%$ & $20-30 \%$ & 20 \\
\hline Jamgiri bit, 363 & 183 & Flat & $0 \%$ & $20-30 \%$ & 30 \\
\hline Talwada 2 bit, compartment 61 & 238 & Flat & $5-10 \%$ & $60-80 \%$ & 30 \\
\hline Kondhala, compartment 58 & 206 & Flat & $0 \%$ & $30-40 \%$ & 20 \\
\hline $\begin{array}{l}\text { Jogisakra-Salmara road, } \\
\text { compartment } 42\end{array}$ & 235 & Flat & $0 \%$ & $>90 \%$ & 30 \\
\hline
\end{tabular}

asl - above sea level.

Table 12: Standard methods used for soil analysis

\begin{tabular}{lll}
\hline Parameter & Standard method & Instrument \\
\hline $\mathrm{pH}$ & Electrometric method & Microprocessor-based pH meter \\
Electrical conductivity & Conductivity meter & $\begin{array}{l}\text { Microprocessor-based electrical } \\
\text { conductivity meter }\end{array}$ \\
Bulk density & Core sampler method & NA \\
Water Holding Capacity & Gravimetric method & K R Box \\
Organic carbon & Walkley and Black method & NA \\
Organic matter & Walkley and Black method & NA \\
\hline
\end{tabular}

NA- Not Applicable

Soil samples brought in the laboratory were opened and spread on a clean filter paper and shed dried. The soil samples were sieved through a standard sieve of pore size of $2 \mathrm{~mm}$ to get a uniform particle size soil sample. The soil sample was then subjected to physicochemical analysis by adopting standard methods (Table 12). For carrying out these characteristic analyses all reagents used were of 'AR' grade (Merck) and prepared with the help of double-distilled water. 


\section{RESULTS AND DISCUSSION}

From the results reported in Table 13, it can be seen that ambient air temperature is in the range of $35.0-40.5^{\circ} \mathrm{C}$ with average $37.5^{\circ} \mathrm{C}( \pm 2.03)$. Atmospheric relative humidity with average $32.16 \%(16.0-54.5 \%)$ indicates relatively lower moisture content in the atmosphere. Soil moisture analysis before and after controlled forest fire from all the six sampling locations revealed that moisture content is absent. Due to high atmospheric temperature $\left(35.0^{\circ} \mathrm{C}-40.5^{\circ} \mathrm{C}\right)$ from the study area and relatively low (32\%) average atmospheric relative humidity resulted in these observations. These conditions may have resulted in the evaporation of soil moisture present in the soil. Thus, soil from the study area was devoid of moisture content.

Soil physical properties

Soil physical properties concerning bulk density, water holding capacity are estimated to ascertain the impacts of controlled forest fires on soil properties. The results obtained for these properties are presented in Table 13. Statistics concerning minimum, maximum, average, standard deviation and $75^{\text {th }}, 95^{\text {th }}$ and $98^{\text {th }}$ percentile is also computed. Impacts of controlled forest fires on soil properties are presented in Table 15.

Bulk density: Bulk density of the soil before and after controlled forest fire from the identified sampling locations from the study area is depicted in Figure 2; whereas, the impact on bulk density is depicted in Figure 3. Average bulk density before controlled forest fire is $1.03 \mathrm{~g} / \mathrm{cm}^{3}$ which got increased to $1.10 \mathrm{~g} / \mathrm{cm}^{3}$ after a controlled forest fire. On comparison of standard deviation in both situations, it is comparable and narrow which indicates observations are in confined range.

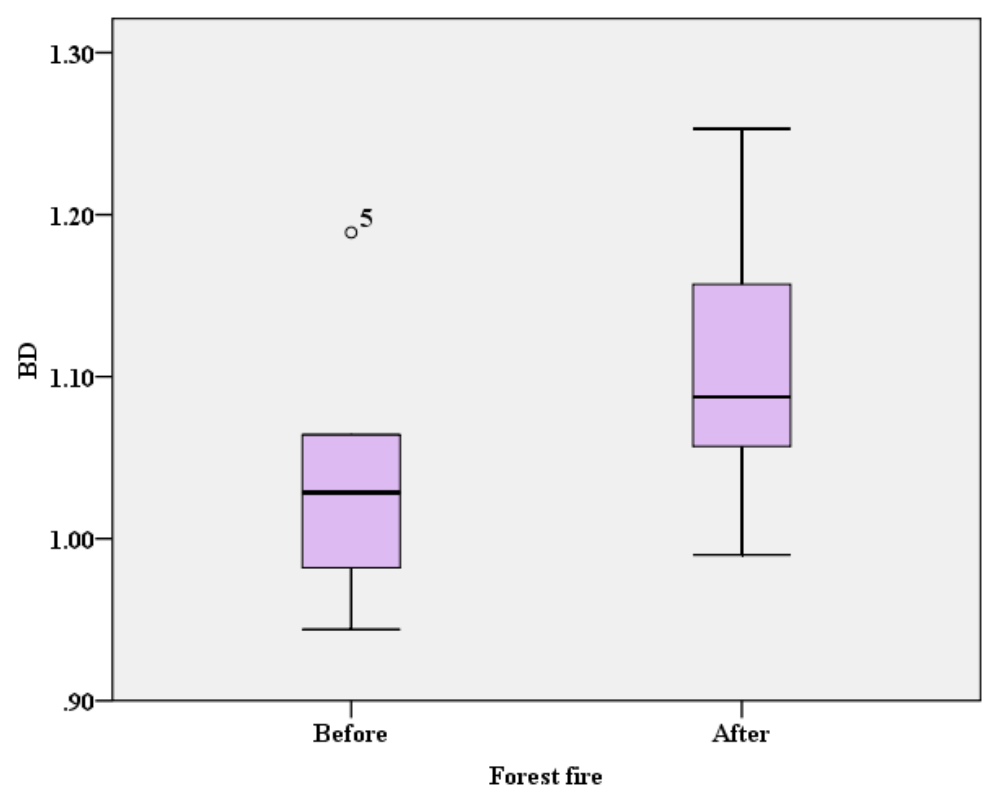

Figure 2: Bulk density of soil before and after controlled forest fires. 


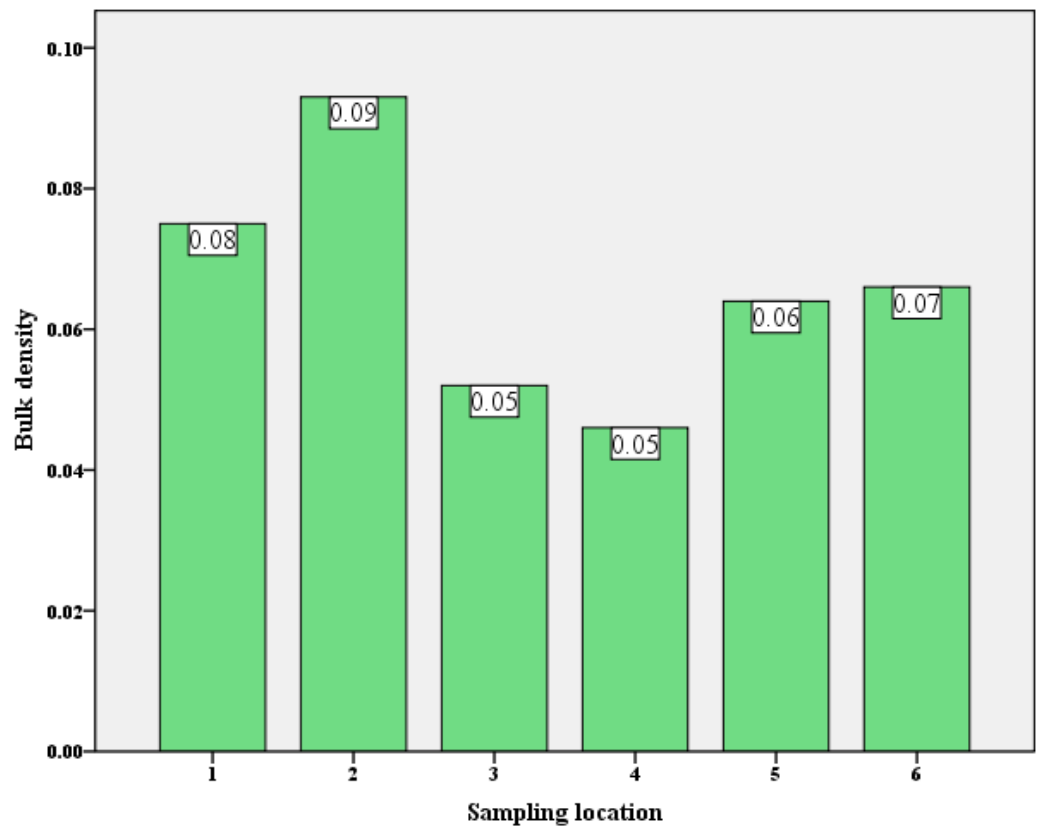

Figure 3: Impact of controlled forest fires on bulk density of soil

It has been observed that there is an increase in bulk density in all sampling locations after a forest fire. After controlled forest fire the air entrapped in the soil particles may get heat up and as a result of which becomes less dense and gets released into the atmosphere. This may have resulted in a reduction in space between soil particles thus increased in bulk density of the soil. Furthermore, the burning of organic matter may also reduce the pore space between the soil particles and leaf litter biomass ash may clog the particle space.

Increased soil bulk density from the study area after a controlled forest fire is in agreement with Kennard and Ghol (2001); Hobbert et al., (2006); Granged et al., (2011a). The reason assigned for change in this soil property is related to the loss of organic matter content and loss of soil structure. It has been reported by Granged et al., (2011a) the bulk density remains increased after three years of prescribed fire. This indicates that forest fire has a long term effect on soil bulk density. An increase in bulk density of soil is because of the collapse of aggregates and clogging of voids by ash and dispersed clay minerals; as a consequence, soil porosity and permeability decrease (Certini, 2005). Bulk density increases with ash depth (Cerda and Doerr, 2008).

Water holding capacity: Water holding capacity of the soil before and after controlled forest fires is depicted in Figure 4. Minimum water holding capacity before controlled forest fire is $22.68 \%$; whereas, maximum $37.32 \%$ and $29.87 \%$ as average. In the case of after controlled forest fire, it reduced down to minimum $21.58 \%$ and maximum $34.63 \%$ with average $29.91 \%$. Average water holding capacity value before and after 
controlled forest fire are comparable. It is observed that out of six sampling locations, $50 \%(n=3)$ have shown an increase in soil's water holding capacity and others have reported a decrease in capacity. The maximum increase in water holding capacity $(3.86 \%)$ is observed at Kothari (sampling location 1) followed by Ghot (1.99\%) (sampling location 2 ). In the case of Talwada (sampling location 4), the maximum decrease in water holding capacity $3.37 \%$ is recorded (Figure 5 ).

Most studies reported that heating of forest soils modifies their wet-ability, and the changes in water repellency are related to temperatures reached (e.g. DeBano and Krammes, 1966; Doerr et al., 2004; Garcia-Corona et al., 2004; Dlapa et al., 2008). Fireinduced water repellency is caused by partial combustion of soil organic matter. Heated hydrophobic organic substances in the topsoil are volatilized and lost upward in the smoke during burning with variable proportion moving downward in response to the temperature gradient in the soil until they condense and coat the mineral soil particles in cooler and deeper soil layers. The volatilization/condensation processes can partly explain the occurrence of strong water repellency in deep soil layers (DeBano et al., 1970). DeBano (1981) found that heating soil to $175-200^{\circ} \mathrm{C}$ resulted in increased water repellency while above $270-300^{\circ} \mathrm{C}$ water repellency was destroyed (Gracio-Corona et al., 2004; Zovala et al., 2010).

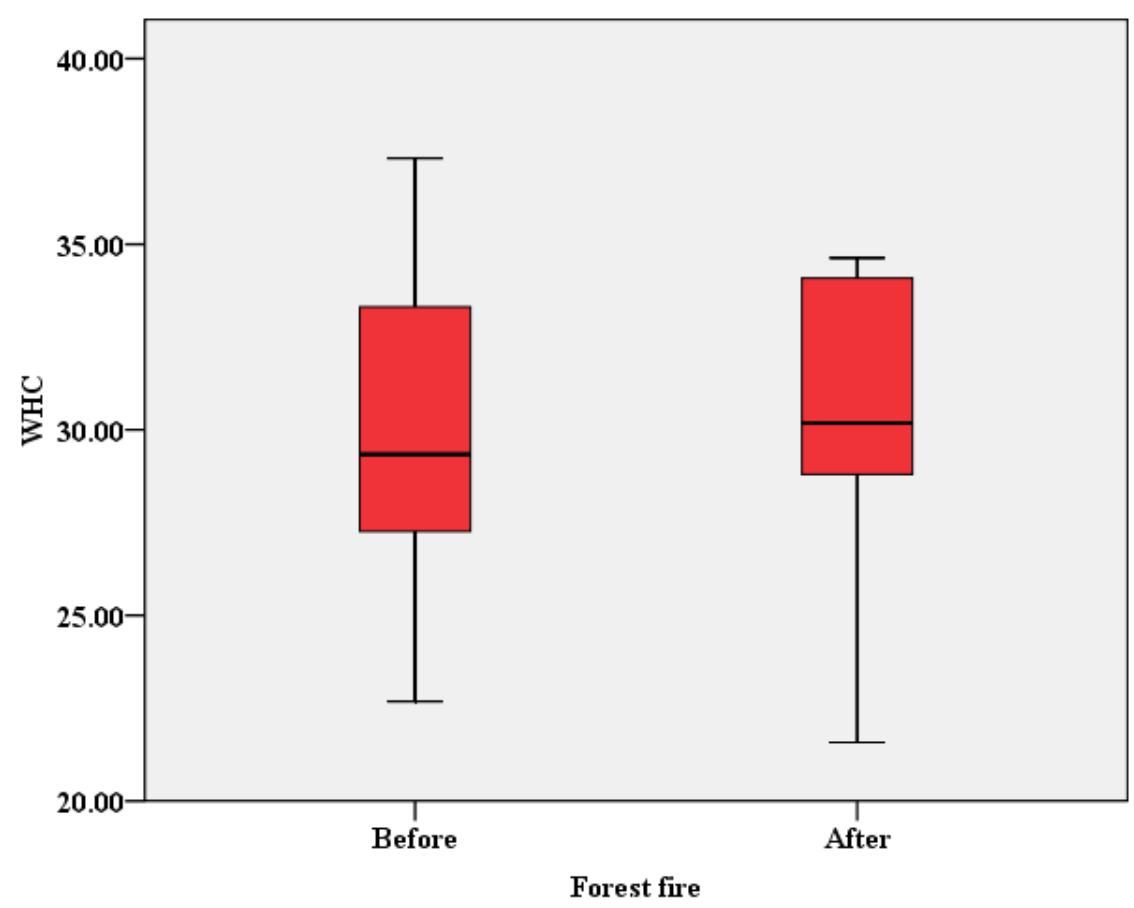

Figure 4: Water holding capacity of soil before and after controlled forest fires. 
Sustainability, Agri, Food and Environmental Research, (ISSN: 0719-3726), X(X), 2021: 231-262

http://dx.doi.org/10.7770/safer-V0N0-art2253

Table 13: Controlled forest fire's impacts on soil's physical properties

\begin{tabular}{|c|c|c|c|c|c|c|c|c|}
\hline \multirow[t]{2}{*}{ Sampling location } & \multirow{2}{*}{$\begin{array}{l}\text { Ambient air } \\
\text { temperature } \\
\left({ }^{\circ} \mathrm{C}\right)\end{array}$} & \multirow{2}{*}{$\begin{array}{l}\text { Atmospheric } \\
\text { relative } \\
\text { humidity (\%) }\end{array}$} & \multicolumn{2}{|c|}{ Soil moisture (\%) } & \multicolumn{2}{|c|}{$\begin{array}{l}\text { Bulk density } \\
\left(\mathrm{g} / \mathrm{cm}^{3}\right)\end{array}$} & \multicolumn{2}{|c|}{$\begin{array}{l}\text { Soil water holding } \\
\text { capacity }(\%)\end{array}$} \\
\hline & & & Before & After & Before & After & Before & After \\
\hline Kothari bit, 330 & 36.5 & 18.0 & Absent & Absent & 0.982 & 1.057 & 30.23 & 34.09 \\
\hline Ghot 1, 850 & 39.5 & 21.5 & Absent & Absent & 1.064 & 1.157 & 28.44 & 30.43 \\
\hline Jamgiri bit, 363 & 40.5 & 16.0 & Absent & Absent & 1.053 & 1.105 & 37.32 & 34.63 \\
\hline $\begin{array}{l}\text { Talwada } 2 \text { bit, compartment no. } \\
61\end{array}$ & 35.0 & 54.5 & Absent & Absent & 0.944 & 0.99 & 33.31 & 29.94 \\
\hline Kondhala, compartment no. 58 & 37.0 & 44.0 & Absent & Absent & 1.189 & 1.253 & 22.68 & 21.58 \\
\hline Jogisakra-Salmara road & 37.0 & 39.0 & Absent & Absent & 1.004 & 1.070 & 27.26 & 28.80 \\
\hline Minimum & 35.0 & 16.0 & - & - & 0.944 & 0.99 & 22.68 & 21.58 \\
\hline Maximum & 40.5 & 54.5 & - & - & 1.189 & 1.253 & 37.32 & 34.63 \\
\hline Average & 37.58 & 32.16 & - & - & 1.039 & 1.105 & 29.87 & 29.91 \\
\hline Standard deviation $( \pm)$ & 2.035 & 15.88 & - & - & 0.085 & 0.090 & 5.060 & 4.704 \\
\hline $75^{\text {th }}$ percentile & 38.87 & 42.75 & - & - & 1.061 & 1.144 & 32.54 & 33.17 \\
\hline $95^{\text {th }}$ percentile & 40.25 & 51.87 & - & - & 1.157 & 1.229 & 36.31 & 34.49 \\
\hline $98^{\text {th }}$ percentile & 40.4 & 53.45 & - & - & 1.176 & 1.243 & 36.91 & 34.57 \\
\hline
\end{tabular}

Before: Before controlled forest fire; After: After a controlled forest fire 


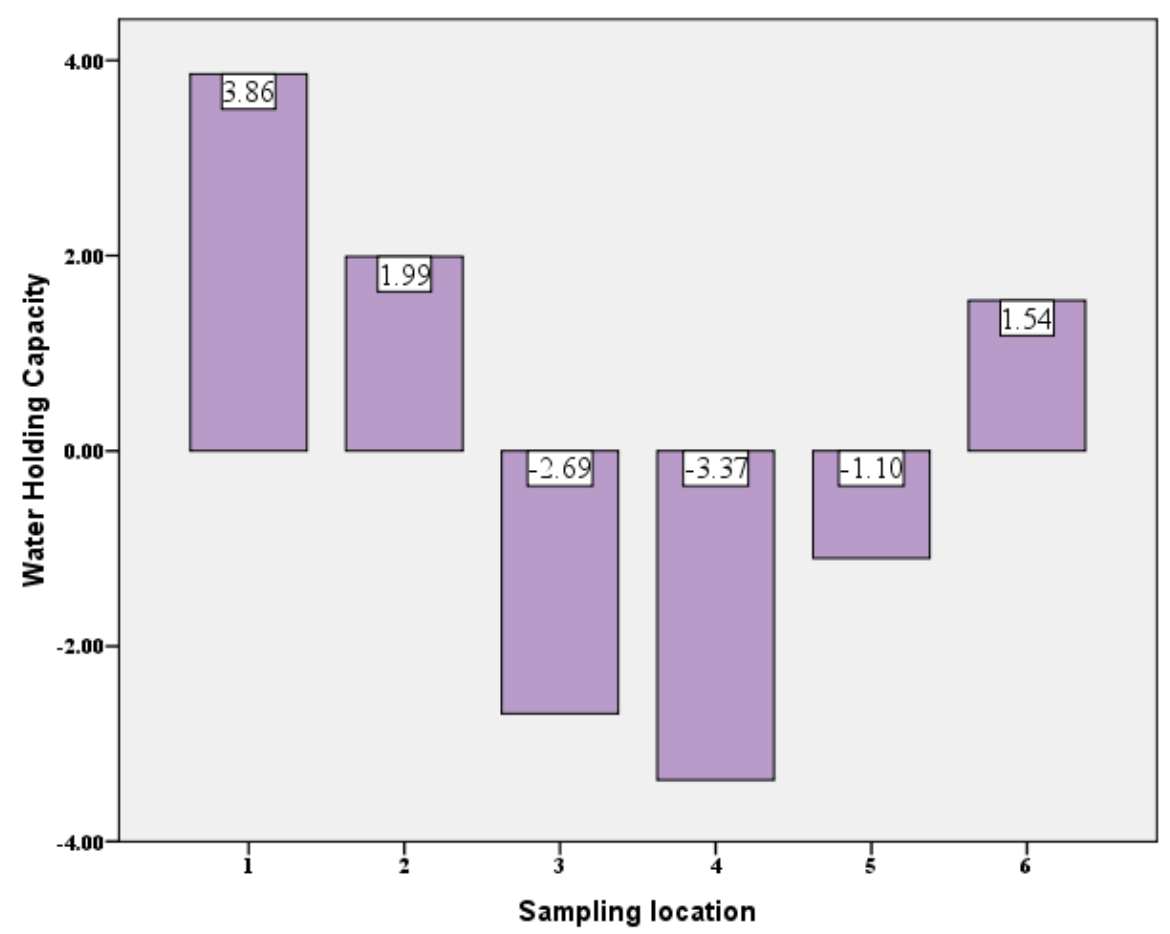

Figure 5: Impact of controlled forest fires on water holding capacity of soil

DeBano (1991) suggested that heating water repellent soils that contained more than $2-3 \%$ organic matter always induce water repellency. Soil water repellency is induced or enhanced at temperatures of $200-250^{\circ} \mathrm{C}$. If the temperature is greater than $300^{\circ} \mathrm{C}$, it can be destroyed. Other factors such as the amount and type of litter consumed and soil moisture immediately before burning can intensify or reduce the water repellency in the soil.

High surface temperature 'burn' off organic materials and create vapours that move downward in response to a temperature gradient and then condense on soil particles causing them to become water repellent (Letey, 2001).

Soil chemical properties

Soil chemical properties concerning $\mathrm{pH}$, electrical conductivity (EC), organic carbon $(\mathrm{OC})$ and organic matter (OM) are estimated to ascertain the impacts of controlled forest fires on soil properties. The results obtained for these properties are presented in Table 14. Statistics concerning minimum, maximum, average, standard deviation and $75^{\text {th }}, 95^{\text {th }}$ and $98^{\text {th }}$ percentile is also computed. Impacts of controlled forest fires on soil properties are presented in Table 15. 
Sustainability, Agri, Food and Environmental Research, (ISSN: 0719-3726), X(X), 2021: 231-262 http://dx.doi.org/10.7770/safer-VONO-art2253

Table 14: Controlled forest fire's impacts on soil's chemical properties

\begin{tabular}{|c|c|c|c|c|c|c|c|c|}
\hline \multirow[t]{2}{*}{ Sampling location } & \multicolumn{2}{|c|}{ Soil pH } & \multicolumn{2}{|c|}{$\begin{array}{l}\text { Electrical conductivity } \\
(\mu \mathrm{S} / \mathrm{cm})\end{array}$} & \multicolumn{2}{|c|}{$\begin{array}{c}\text { Soil organic carbon } \\
(\%)\end{array}$} & \multicolumn{2}{|c|}{$\begin{array}{c}\text { Soil organic matter } \\
(\%)\end{array}$} \\
\hline & Before & After & Before & After & Before & After & Before & After \\
\hline Kothari bit, 330 & 5.99 & 5.63 & 45.7 & 32.8 & 1.40 & 1.55 & 2.41 & 2.67 \\
\hline Ghot 1, 850 & 6.28 & 5.65 & 44.9 & 38.4 & 1.48 & 1.01 & 2.54 & 1.74 \\
\hline Jamgiri bit, 363 & 5.78 & 5.83 & 43.9 & 48.0 & 1.79 & 1.48 & 3.08 & 2.54 \\
\hline $\begin{array}{l}\text { Talwada } 2 \text { bit, compartment no. } \\
61\end{array}$ & 5.20 & 5.72 & 41.1 & 25.5 & 1.79 & 1.48 & 3.08 & 2.54 \\
\hline Kondhala, compartment no. 58 & 5.53 & 5.85 & 43.7 & 37.0 & 2.07 & 0.15 & 3.56 & 0.26 \\
\hline Jogisakra-Salmara road & 5.85 & 6.04 & 43.5 & 38.3 & 3.98 & 2.25 & 6.85 & 3.88 \\
\hline Minimum & 5.20 & 5.63 & 41.10 & 25.50 & 1.40 & 0.15 & 2.41 & 0.26 \\
\hline Maximum & 6.28 & 6.04 & 45.70 & 48.00 & 3.98 & 2.25 & 6.85 & 3.88 \\
\hline Average & 5.77 & 5.78 & 43.80 & 36.66 & 2.08 & 1.32 & 3.58 & 2.27 \\
\hline $75^{\text {th }}$ percentile & 5.95 & 5.84 & 44.65 & 38.37 & 2.00 & 1.53 & 3.44 & 2.63 \\
\hline $95^{\text {th }}$ percentile & 6.20 & 5.99 & 45.60 & 45.60 & 3.50 & 2.08 & 6.02 & 3.57 \\
\hline $98^{\text {th }}$ percentile & 6.25 & 6.02 & 47.04 & 47.04 & 3.79 & 2.18 & 6.52 & 3.75 \\
\hline
\end{tabular}

Before: Before a controlled forest fire; After: After controlled forest fires 
$\mathrm{pH}$ : Results for soil $\mathrm{pH}$ before and after controlled forest fires are depicted in Figure 6. From the figure, it can be seen that soil has acidic $\mathrm{pH}$ from the sampling locations. Average soil pH before and after a controlled forest fire is 5.77 and 5.79 respectively, both are comparable. In case of standard deviation, before controlled forest fire $\mathrm{pH}$ values deviate more than the after controlled forest fires situation. Impacts of controlled forest fires on soil pH revealed that, of the sampling locations, two have reported a decrease in soil $\mathrm{pH}$ after forest fires; whereas, at four sampling locations increased in soil $\mathrm{pH}$ is observed (Figure 7). The maximum reduction of $\mathrm{pH}(-0.63)$ is observed at Ghot (sampling location 2) on the other hand maximum increase (0.52) in Talwada (sampling location 4).

Increase in soil $\mathrm{pH}$ after a prescribed fire is due to release of base cations from the combustion of organic matter (Guinto et al., 2001; Kennard and Gholz, 2001; Arocena and Opio, 2003; Ubeda et al., 2005; Neill et al., 2007; Granged et al., 2011a, Scharenbroch et al., 2012; Muqaddas et al., 2015). Burning grassland vegetation converts grasses into soluble salts that are incorporated into soils (Sherman et al., 2005). The presence of ash may increase soil pH due to its high pH (Molina et al., 2007; Schafer and Mack, 2010). An increase in soil pH after a forest fire is reported by Tufeccioglu et al., (2010); Aref et al., (2011), Boerner et al., (2009). A significant increase in soil pH occurs only at elevated temperatures $\left(450-500^{\circ} \mathrm{C}\right)$ (Certini, 2005).

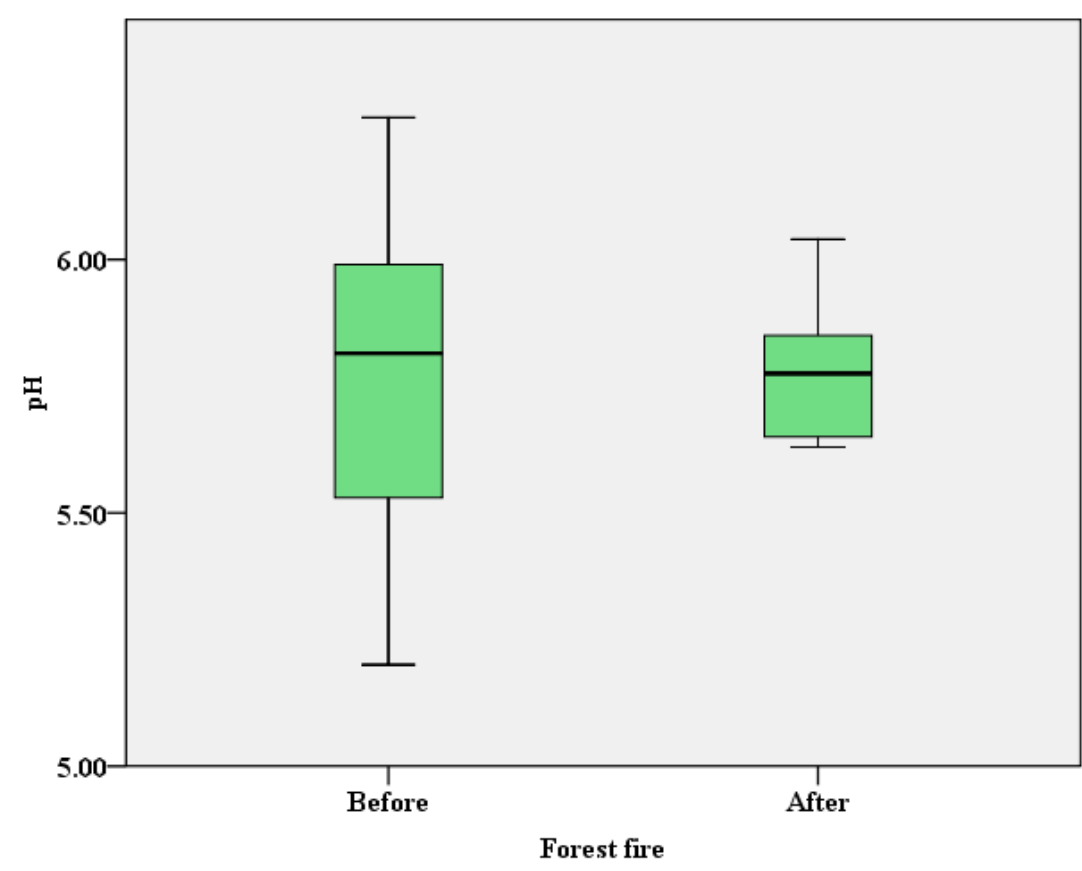

Figure 6: Soil pH before and after controlled forest fires 


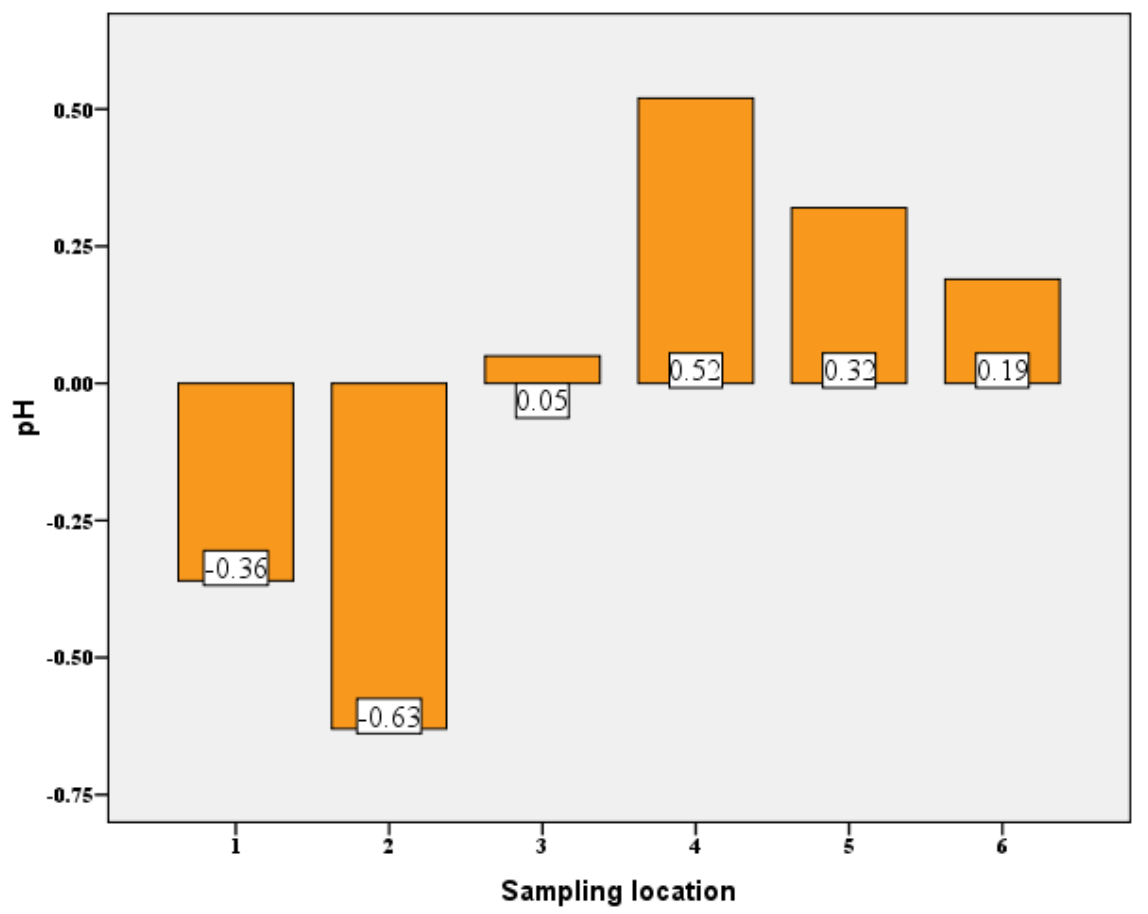

Figure 7: Impact of controlled forest fires on soil pH

Scotter (1963) reported increased pH values in all burned over areas. In Sweden, Uggla (1958) reported for about 25 years $\mathrm{pH}$ values were higher on burns than an adjacent un-burnt area. The severity of the burn, may, however, may influence the number of years that the higher $\mathrm{pH}$ values will be restrained.

Soil acidity usually decreases after the fire due to the destruction of organic acids and the contribution of carbonates, bases, and oxides from ash (Kutiel et al., 1990; Ulery et al., 1995; Granged et al., 2011a,b). After high-intensity fire and reduction of soil organic matter by combustion, $\mathrm{pH}$ can increase significantly in 4 or 5 units (Ulery et al., 1995) mainly due to the loss of $\mathrm{OH}^{-}$groups from clay minerals, the formation of oxides (Giovannin et al., 1988, 1990), the release of cations (Giardina et al., 2000; Arocena and Opio, 2003; Dikici and Yilma, 2006) or replacement of protons in the cation exchange capacity (Arocena and Opio, 2003; Terefe et al., 2008).

Soil $\mathrm{pH}$ increased significantly one year after the wildfire is reported by several authors, who have reported an increase in soil $\mathrm{pH}$ following forest burning and for the effect to last for one to several years (Ponder et al., 2009; Granged et al., 2011). Ubeda et al., (2005) observed that $\mathrm{pH}$ returned to pre-fire values just one year after the fire. This increase is generally due to the combustion of organic matter and ash production. Burns are presumed to cause losses of un-dissociated organic acids in the litter and soil by combustion, removing them from the system (Arocena and Opio, 2003). Also, the leaching of alkaline metals from the ash into the soil complex and the associated 
Sustainability, Agri, Food and Environmental Research, (ISSN: 0719-3726), X(X), 2021: 231-262 http://dx.doi.org/10.7770/safer-VONO-art2253

Table 15: Impacts of controlled forest fires on soil properties

\begin{tabular}{|c|c|c|c|c|c|c|}
\hline Sampling Iocation & $\begin{array}{l}\text { Bulk } \\
\text { density }\end{array}$ & $\begin{array}{l}\text { Water } \\
\text { holding } \\
\text { capacity }\end{array}$ & $\mathrm{pH}$ & $\begin{array}{l}\text { Electrical } \\
\text { conductivity }\end{array}$ & $\begin{array}{l}\text { Organic } \\
\text { carbon }\end{array}$ & $\begin{array}{l}\text { Organic } \\
\text { matter }\end{array}$ \\
\hline Kothari bit, 330 & 0.075 & 3.86 & -0.36 & -12.9 & 0.156 & 0.26 \\
\hline Ghot 1, 850 & 0.093 & 1.99 & -0.63 & -6.5 & -0.468 & -0.8 \\
\hline Jamgiri bit, 363 & 0.052 & -2.69 & 0.05 & 4.1 & -0.311 & -0.54 \\
\hline \multicolumn{7}{|l|}{ Talwada 2 bit, compartment no. } \\
\hline 61 & 0.046 & -3.37 & 0.52 & -15.6 & -0.311 & -0.54 \\
\hline Kondhala, compartment no. 58 & 0.064 & -1.1 & 0.32 & -6.7 & -1.917 & -3.294 \\
\hline Jogisakra-Salmara road & 0.066 & 1.54 & 0.19 & -5.2 & -1.728 & -2.97 \\
\hline Minimum & 0.046 & -3.37 & -0.63 & -15.6 & -1.917 & -3.29 \\
\hline Maximum & 0.093 & 3.86 & 0.52 & 4.1 & 0.156 & 0.26 \\
\hline Average & 0.066 & 0.038 & 0.015 & -7.13 & -0.763 & -1.314 \\
\hline Standard deviation $( \pm)$ & 0.0167 & 2.864 & 0.432 & 6.86 & 0.848 & 1.456 \\
\hline Variance & 0.0002 & 8.205 & 0.187 & 47.09 & 0.720 & 2.120 \\
\hline Kurtosis & 0.2323 & -1.83 & -0.91 & 0.752 & -1.607 & -1.608 \\
\hline
\end{tabular}

Bulk density in $\mathrm{g} / \mathrm{cm}^{3}$; Water holding capacity in \%; $\mathrm{pH}$ no unit; Electrical conductivity in $\mu \mathrm{S} / \mathrm{cm}$; Organic carbon and Organic matter in \%. Values represent different between before and after a controlled forest fire.

Negative values indicate a decrease in the respective parameter of soil sample than the before controlled forest fire and other cases increase in the respective properties in after controlled forest fire. 
consumption of hydrogen ions in the formation of water could result in an increase in $\mathrm{pH}$ after the fire (Hamman et al., 2008; Granged et al., 2011).

Electrical conductivity: Soil electrical conductivity before and after controlled forest fires from the study area is depicted in Figure 8. It can be observed that before controlled forest fire average electrical conductivity is more $(43.8 \mu \mathrm{S} / \mathrm{cm})$; whereas, after controlled forest fires it reduces to $36.6 \mu \mathrm{S} / \mathrm{cm}$. The standard deviation for before and after controlled forest fires indicates that before forest fire electrical conductivity values are comparatively closer than after controlled forest fires. Soil electrical conductivity decreased after controlled forest fires are observed in the study area from five locations (Figure 9). The reason assigned for this is a consequence of the decrease in many of the extractable soil nutrients (Brye, 2006).

In case of an increase in electrical conductivity (at sampling location 3, Jamgiri bit) it may be due to the release of soluble inorganic ions during the combustion of soil organic matter (Granged et al., 2011a; Scharenbroch et al., 2012). Long term formation of black carbon is also responsible for an increase in electrical conductivity in soil. Electrical conductivity may also decrease in soil exposed to temperatures of about $500^{\circ} \mathrm{C}$, due to the destruction of clay minerals, the formation of oxides and the formation of coarse particles (Terefe et al., 2008). Fire decreased the electrical conductivity significantly in the burned site is reported by Aref et al., (2011). It is further reported that electrical conductivity (+/) significantly decreased from 2.13 in unburnt sites to $1.1 \mathrm{dSm}^{-1}$ in burnt sites in Al Hilia forest (Saudi Arabia).

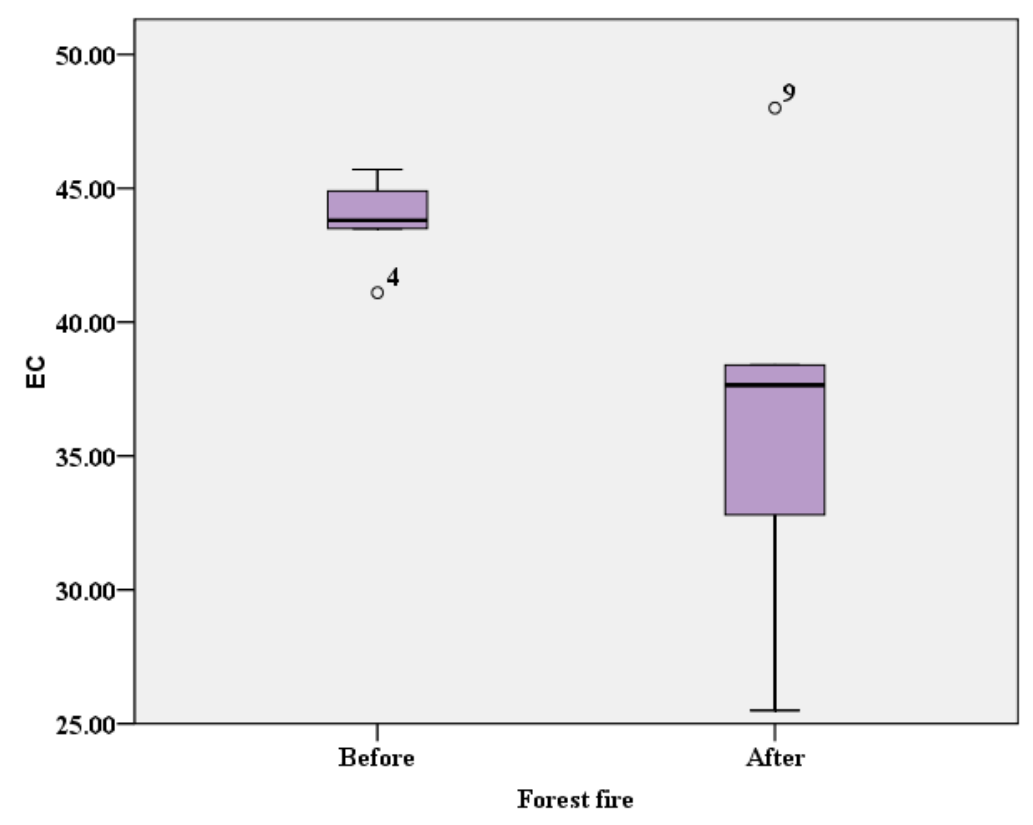

Figure 8: Electrical conductivity of soil before and after controlled forest fires 


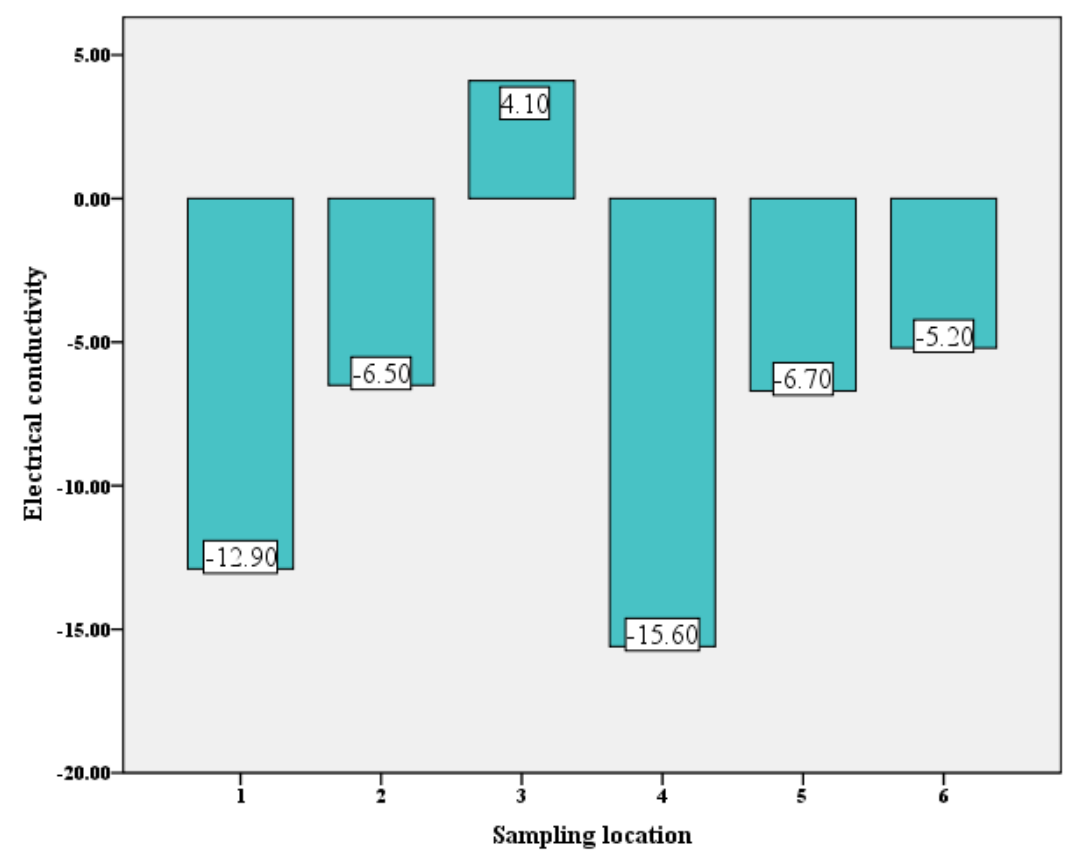

Figure 9: Impact of controlled forest fires on electrical conductivity of soil

Organic carbon and organic matter: Observations' regarding soil organic carbon and organic matter before and after controlled forest fires are presented in Table 14 and depicted in Figures 10 and 11 respectively. Average soil organic carbon before controlled forest fires is $2.08 \%$ which got reduced to $1.32 \%$. Soil organic matter values for a before controlled forest fire is marginally higher than after controlled forest fires. In the case of organic matter, before controlled forest fire its average value is $3.58 \%$; whereas, after controlled forest fires it is $2.27 \%$. Soil organic matter indicates, widespread in observations (2.41-6.85\%) before controlled forest fire than after (0.26-3.88\%). In all sampling locations decrease in organic carbon and organic matter percentage is observed except Kothari (sampling location 1 ) in which marginally increase in percentage is noticed (Figures 12 and 13 respectively). This increase in organic carbon and organic matter may be due to not enough temperature of forest fire for the oxidation of organic matter present in the soil. Furthermore, incorporation of charred material and ash of dried biomass can also result in this finding. Also, the input of root biomass may result in this observation. Maximum (1.92\%) reduction in organic carbon is observed at Kondhala (sampling location 5 ) which is closely followed by Jogisakra- Salmara (1.73\%) (sampling location 6). Similar observations are recorded for organic matter also (Figure 13). 
Sustainability, Agri, Food and Environmental Research, (ISSN: 0719-3726), X(X), 2021: 231-262 http://dx.doi.org/10.7770/safer-V0NO-art2253

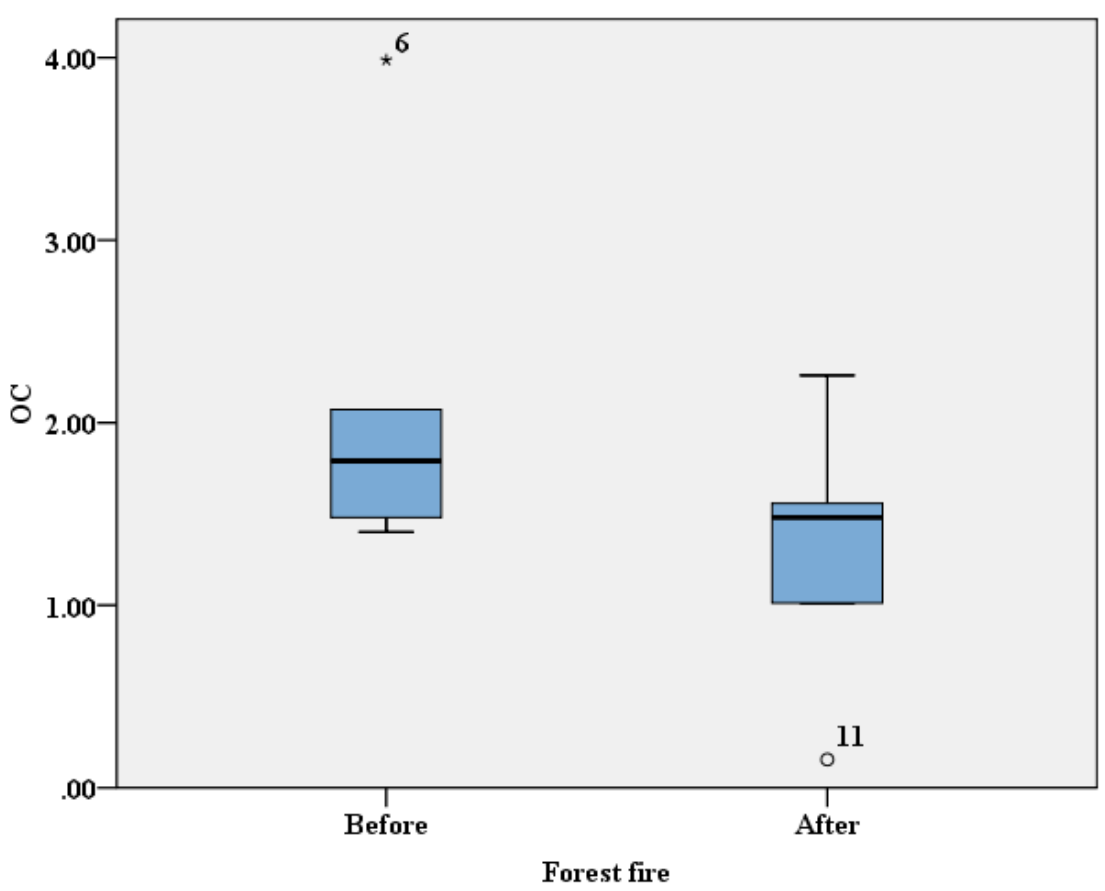

Figure 10: Organic carbon of soil before and after controlled forest fires

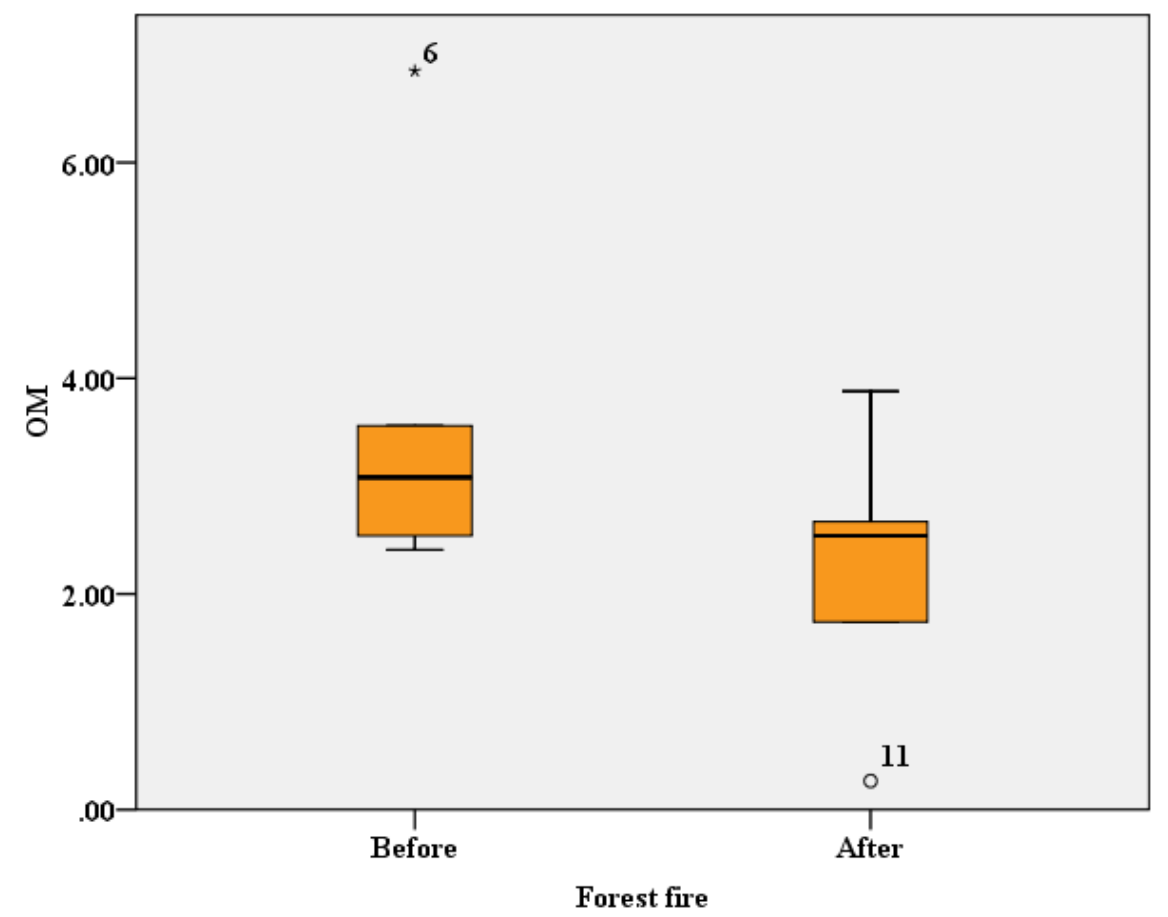

Figure 11: Organic matter of soil before and after controlled forest fires 
Sustainability, Agri, Food and Environmental Research, (ISSN: 0719-3726), X(X), 2021: 231-262 http://dx.doi.org/10.7770/safer-V0NO-art2253

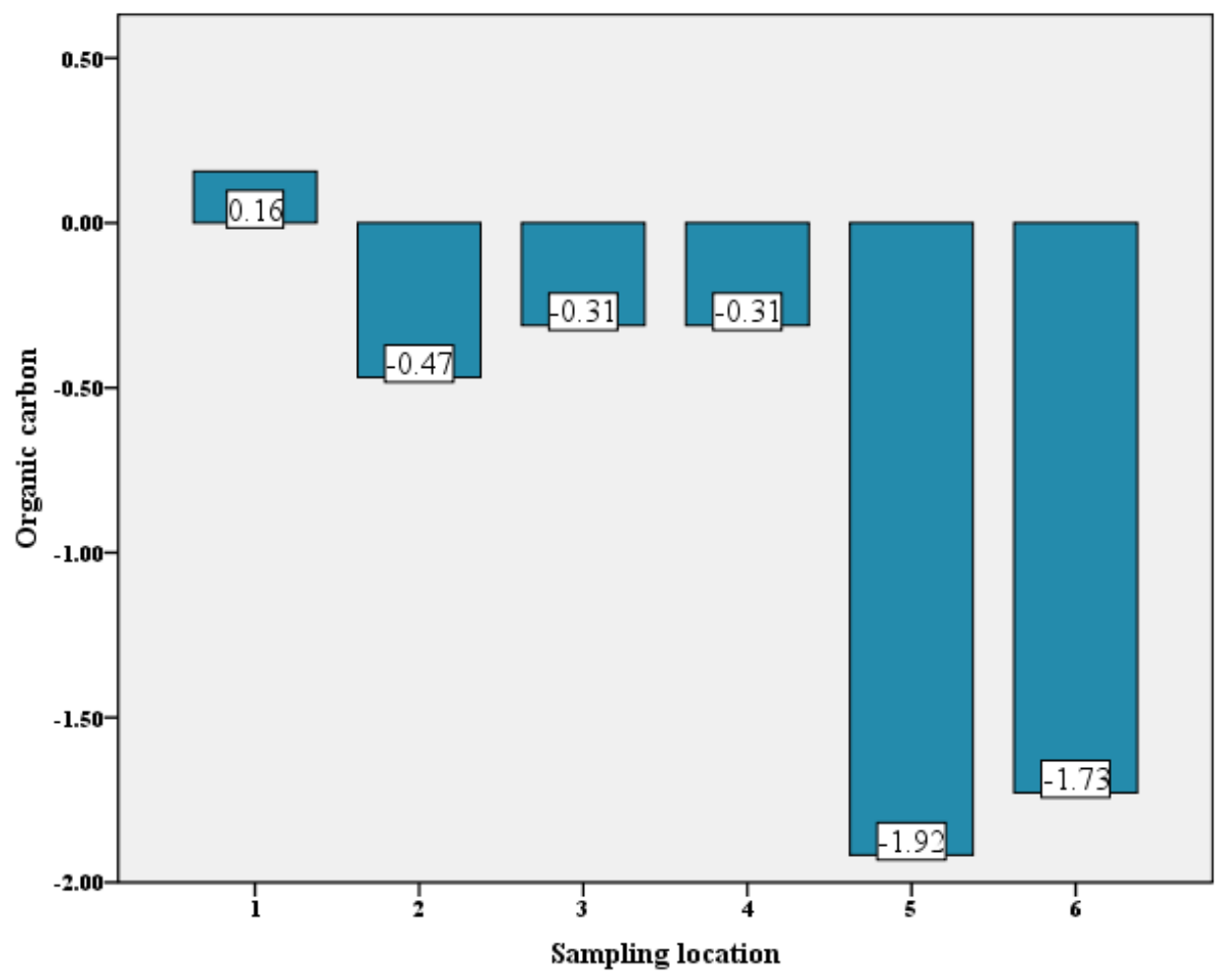

Figure 12: Impact of controlled forest fires on organic carbon of soil

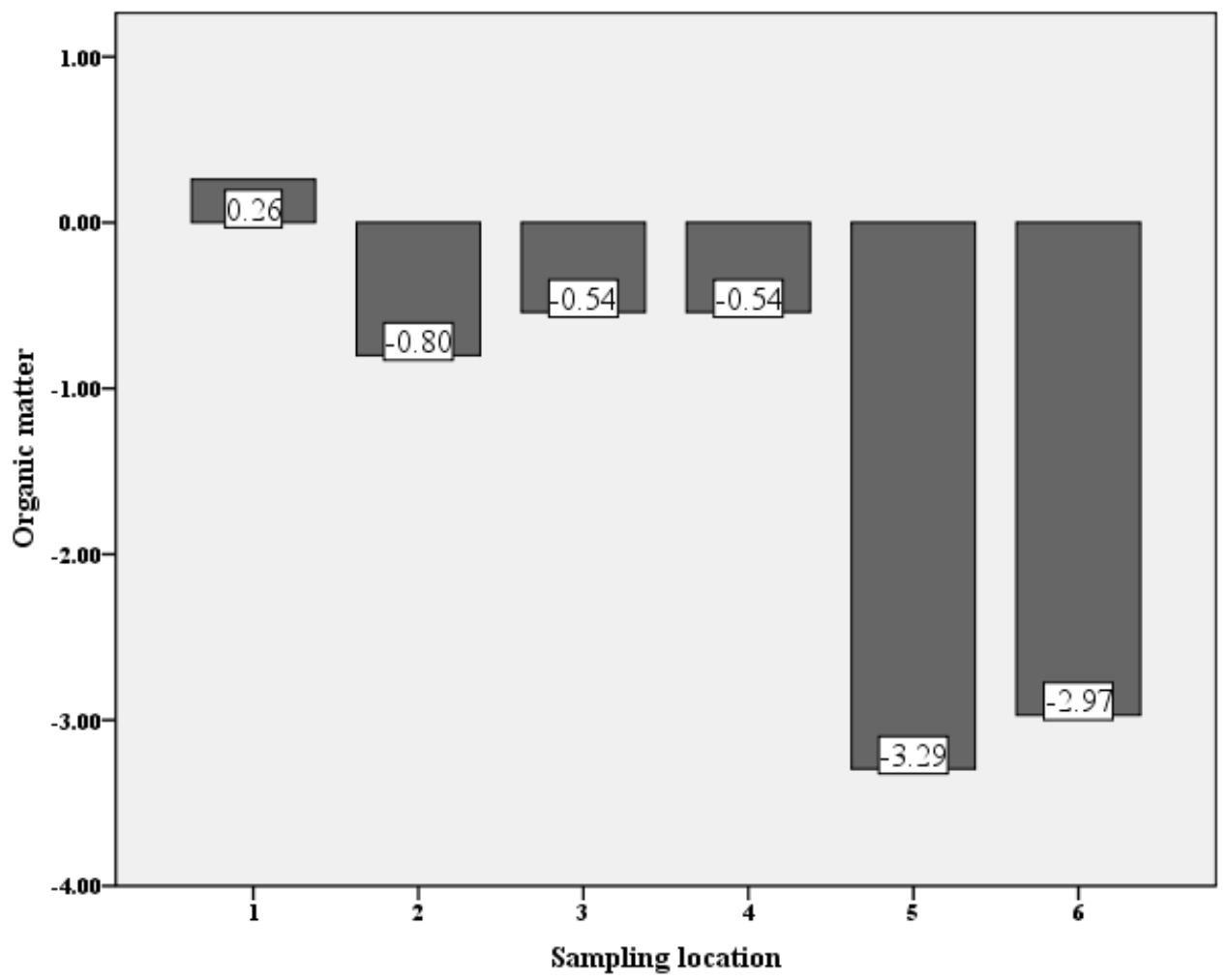

Figure 13: Impact of controlled forest fires on organic matter of soil 
Sustainability, Agri, Food and Environmental Research, (ISSN: 0719-3726), X(X), 2021: 231-262 http://dx.doi.org/10.7770/safer-V0NO-art2253

Soil organic carbon and organic matter in Kondhala (sampling location 5) and Jogisakra (sampling location 6) before controlled forest fire on comparison with other sampling locations was found to be higher. The reason for these observations can be assigned to no previous forest fire history in these sampling locations in the last 2-3 years. As a result of which there is an accumulation of a large quantity of leaf litter on the forest floor. This leaf litter is a dead organic matter; the detritus food chain may have started. Breakdown of organic matter present in leaf litter by microorganism enriched forest floor. This activity may have resulted in elevated organic carbon and organic matter.

After controlled forest fires at these sampling locations, it can be observed that there is a significant reduction in organic carbon and organic matter content of the forest floor. In the case of Kondhala (sampling location 5) organic carbon content reduction was $72 \%$; whereas, $56 \%$ in Jogisakhra (sampling location 6).

Soil organic matter decrease is reported by Granged et al., (2011a) with an assertion that forest fire temperature reaches $420^{\circ} \mathrm{C}$. An increase in temperature may have resulted in the oxidation of soil organic carbon and organic matter. Muqaddas et al., 2015 reported a decrease in total carbon which is attributed to carbon loss as $\mathrm{CO}_{2}$ into the atmosphere. An increase in soil organic matter is reported by Kennard and Gholz (2001) with a reason for change as the incorporation of unburned or partially burned slash fragment into the soil (low intensity). The input of root biomass is another reason for an increase in soil organic matter and total carbon (Brye, 2006). Scharenbroch et al., (2012) reported an increase in total carbon due to not enough temperature of forest fire for the oxidation of organic matter. Temporary enrichment of soil from ash and charred material results into an increase in soil organic matter is reported by Shakesby et al., (2015); Alcaniz et al., (2016).

Infrequent fires, on the other hand, allow for greater fuel accumulation between successive burns and therefore burn hotter. Such high-intensity fires can result in soil nitrogen volatilisation and a reduction in soil organic matter. The result is reduced soil nutrient availability, accompanied by increased bulk density and decreased porosity and soil water holding capacity (Neary et al., 1999).

As conclusion, the impacts of controlled forest fire on soil physic-chemical properties viz., water holding capacity, $\mathrm{pH}$, electrical conductivity, organic carbon and organic matter will be of short term and reversible duration, except for bulk density and water holding capacity which will have long term impact. In those sampling location (Kondhala, sampling location 5 and Jogisakra, sampling location 6) where forest fire does not occur in last 2-3 years, it has observed that the forest floor is enriched with organic carbon and organic matter due to the degradation of leaf litter biomass by micro- 
organisms present in the soil. Thus, if forest fire is controlled it will enrich the soil with carbon which results in the growth of plants and thus helps in an increase in biodiversity.

In those areas where forest fire does not take place in 2-3 years the large quantity of leaf litter biomass will be collected. These areas when burn it will burn with high fire intensity. Such fires will burn forest floor severely and energy (heat) produce by them will adversely impact flora and fauna. Thus, such an area should be critically monitored and to avoid adverse impacts 'controlled or prescribed' fire activities should be attempted.

\section{ACKNOWLEDGMENTS}

The author is thankful for the financial assistance provided by the Forest Department, Gadchiroli, Maharashtra, India for executing this study.

\section{REFERENCES}

Agricultural Contingency Plan of the Gadchiroli district. pp. 1-23.

Alcañiz, M., Outeiro, L., Francos, M., Farguell, J. and Úbeda, X. (2016). Long-term dynamics of soil chemical properties after a prescribed fire in a Mediterranean forest (Montgrí Massif, Catalonia, Spain). Science of the Total Environment, 572: 13291335.

Alcaniz, M., Outeiro, L., Francos, M. and Ubeda, X. (2018). Effects of prescribed fires on soil properties: A review. Science of the Total Environment, 613-614: 944-957.

Annual Administrative Report 2016-17. Forest Department, Government of Maharashtra.

Aref, I.M., ElnAtta, H.A. and Ghamade, A.R. (2011). Effects of forest fires on tree diversity and some soil properties. International Journal of Agriculture and Biology, 13: 659664.

Arocena, J.M. and Opio, C. (2003). Prescribed fire-induced changes in properties of subboreal forest soils. Geoderma, 113: 1-16.

Badia, D. and Marti, C. (2003). Plant ash and heat intensity effects on chemical and physical properties of two contrasting soils. Arid Land Research Management, 17: 23-41.

Boerner, R.E., Huang, J. and Hart, S.C. (2009). Impacts of fire and fire surrogate treatments on forest soil properties: A meta-analytical approach. Ecological Applications, 19(2): 338-358.

Brye, K.R. (2006). Soil physicochemical changes following 12 years of annual burning in a humid subtropical tall grass prairie: A hypothesis. Acta Oecologica, 30: 407-413.

Carballas, T. (1993). Organic matter, nitrogen, phosphorus and microbial population evolution in forest humiferous acid soils after wildfires, in: Trabaud, L., Prodon, R., 
(Eds.), Fire in Mediterranean ecosystems. Ecosystems Research Series EEC, report no. 5, Brussels, pp. 379- 385.

Census of India, 2011 (2011). District Census Handbook. Gadchiroli district. Directorate of Census Operations Maharashtra.

Cerdà, A. and Doerr, S.H. (2008). The effect of ash and needle cover on surface runoff and erosion in the immediate post-fire period. Catena, 74(3): 256-263.

Certini, G. (2005). Effect of fire on properties of soil-A review. Oecologia, 143: 1-10.

Dlapa, P., Šimkovic Jr., I., Doerr, S.H., Šimkovic, I., Kanka, R. and Mataix-Solera, J. (2008). Application of thermal analyses to elucidate water repellency changes in heated soils. Soil Science Society of America Journal, 72: 1-10.

DeBano, L.F. and Krammes, J.S. (1966). Water repellent soils and their relation to wildfire temperatures. International Bulletin of the Association of Hydrological Scientists, 2: 14-19.

DeBano, L.F., Mann, L.D. and Hamilton, D.A. (1970). Translocation of hydrophobic substances into soil by burning organic litter. Soil Science Society of America Journal, 34: 130-133.

DeBano, L.F., Dunn, P.H. and Conrad, C.E. (1977). Fire's effect on physical and chemical properties of chaparral soils. I. Soil nitrogen. Soil Science Society of America Journal, 43: 504-509.

DeBano, L.F. (1981). Water Repellent Soils: A State-of-the-Art. US Department of Agriculture Forest Service General Technical Report, PSW-46, Berkeley, CA, p. 21.

DeBano, L.F. (1991). Effects of fire on soil properties. General Technical Report, INT-286, USDA Forest Services, Berkeley, CA.

DeBano, L.F. (1996). Formation of non-wettable soils involves heat transfer mechanism. USDA Forest Service Research Note PSW-132, Berkeley, CA.

Dikici, H. and Yilmaz, C.H. (2006). Peat fire effects on some properties of an artificially drained peatland. Journal of Environmental Quality, 35: 866-870.

Doerr, S.H., Blake, W.H., Shakesby, R.A., Stagnitti, F., Vuurens, S.H., Humphreys, G.S. and Wallbrink, P. (2004). Heating effects on water repellency in Australian eucalypt forest soils and their value in estimating wildfire soil temperatures. International Journal of Wildland Fire, 13: 157-163.

FAO (2015). FAO, Global Forest Resources Assessment 2015, UN Food and Agriculture Organization, Rome.

Fernandez, I., Cabaneiro, A. and Carballas, T. (1997). Organic matter changes immediately after a wildfire in an Atlantic forest soil and comparison with laboratory soil heating. Soil Biology and Biochemistry, 29(1): 1-11. 
García-Corona, R., Benito, E., de Blas, E. And Varela, M.E. (2004). Effects of heating on some soil physical properties related to its hydrological behaviour in two northwestern Spanish soils. International Journal of Wildland Fire, 13: 195-199.

Giardina, C.P., Sanford, R.L. and Dockersmith, I.C. (2000). Changes in soil phosphorus and nitrogen during slash-and burn clearing of a dry tropical forest. Soil Science Society of America Journal, 64: 339-405.

Giovannini, G., Lucchesi, S. and Giachetti, M. (1988). Effect of heating on some physical and chemical parameters related to soil aggregation and erodibility. Soil Science, 146: 255-262.

Granged, A.J.P., Jordán, A., Zavala, L.M., Muñoz-Rojas, M. and Mataix-Solera, J. (2011a). Short-term effects of experimental fire for a soil under eucalyptus forest (SE Australia). Geoderma, 167-168: 125-134.

Granged, A.J.P., Zavala, L.M., Jordán, A. and Bárcenas-Moreno, G. (2011b). Post-fire evolution of soil properties and vegetation cover in a Mediterranean heath land after experimental burning: A 3-year study. Geoderma, 164: 85-94.

Guinto, D.F., Xu, Z.H., House, A.P.N. and Saffigna, P.G. (2001). Soil chemical properties and forest floor nutrients under repeated prescribed-burning in eucalypt forest of South-East Queensland, Australia. New Zeeland Journal of Forest Science, 31(2): 170-187.

Hamman, S.T., Burke, I.C. and Knapp, E.E. (2008). Soil nutrients and microbial activity after early and late season prescribed burns in a Sierra Nevada mixed conifer forest. Forest Ecology and Management, 256: 367-374.

Hansen, M.C., Potapov, P.V., Moore, R., Hancher, M., Turubanova, S.A., et al., (2013). High-Resolution Global Maps of 21st-Century Forest Cover Change. Science, 342 (15 November): 850-853.

Hernández, T., García, C. and Reinhardt, I. (1997). Short-term effect of wildfire on the chemical, biochemical and microbiological properties of Mediterranean pine forest soils. Biology and Fertility of Soils, 25: 109-116.

Hubbert, K.P., Preisler, H.K., Wohlgemuth, P.M., Graham, R.C. and Narog, M.G. (2006). Prescribed burning effects on soil physical properties and soil water repellency in a steep chaparral watershed, southern California, USA. Geoderma, 130(3-4): 284298.

Kennard, D.K. and Gholz, H.L. (2001). Effects of high and low intensity fires on soil properties and plant growth in a Bolivian dry forest. Plant and Soil, 234: 119-129.

Kutiel, P. and Naveh, Z. (1987). The effect of fire on nutrients in a pine forest soil. Plant and Soil, 104: 269-274. 
Kutiel, P. and Inbar, M. (1993). Fire impacts on soil nutrients and soil erosion in a Mediterranean pine forest plantation. Catena, 20: 129-139.

Letey, J. (2001). Causes and consequences of fire-induced soil water repellency. Hydrological Processes, 15(15): 2867-2875.

Maksimova, E. and Abakumov, E. (2014). Wildfire effects on biological properties of soils in forests-steppe ecosystems of Russia. Soil Earth Discussion, 6: 71-90.

Mataix-Solera, J., Gómez, I., Navarro-Pedreño, J., Guerrero, C. and Moral, R. (2002). Soil organic matter and aggregates affected by wildfire in a Pinus halepensis forest in Mediterranean environment. International Journal of Wildland Fire, 11: 107-111.

Molina, M., Fuentes, R., Calderón, R., et al., (2007). Impact of forest fire ash on surface charge characteristics of Andisols. Soil Science, 172(10): 820-834.

Muqaddas, B., Zhou, X., Lewis, T., Wild, C. and Chen, C. (2015). Long-term frequent prescribed fire decreases surface soil carbon and nitrogen pools in wet sclerophyll forest of Southeast Queensland, Australia. Science of the Total Environment, 536: 39-47.

Neary, D.G., Klopatek, C.C., De Bano, L.F. and Ffolliott, P.F. (1999). Fire effects on belowground sustainability: A review and synthesis. Forest Ecology and Management, 122: 51-71.

Neill, C., Patterson, W.A., III and Crary, D.W., Jr. (2007). Responses of soil carbon, nitrogen and cations to the frequency and seasonality of prescribed burning in a Cape Cod oak-pine forest. Forest Ecology and Management, 250: 234-243.

Ponder, F. Jr., Tadros, M. and Loewenstein, E.F. (2009). Microbial properties and litter and soil nutrients after two prescribed fires in developing savannas in an upland Missouri Ozark Forest. Forest Ecology and Management, 257: 755-763.

Rastad, H. (2009). Study of fire effect on soil physical and chemical properties and regeneration at conifer stands of Guilan province. Case study Siahkal forests. M.S. Thesis. University of Gillan, pp. 95.

Savage, S.M. (1974). Mechanism of fire-induced water repellency in soil. Soil Science Society America Proceedings. 38, 652-657.

Scharenbroch, B.C., Nix, B., Jacobs, K.A. and Bowles, M.L. (2012). Two decades of lowseverity prescribed fire increases soil nutrient availability in Midwestern, USA oak (Quercus) forest. Geoderma, 183-184: 89-91.

Schafer, J.L. and Mack, M.C. (2010). Short-term effects of fire on soil and plant nutrients. Plant Soil, 334: 433-447.

Scotter, G.W. (1963). Effects of forest fires on soil properties in northern Saskatchewan. 412-421. 
Shakesby, R.A., Bento, C.P.M., Ferreira, C.S.S., Ferreira, A.J.D., Stoof, C.R., Urbanek, E. and Walsh, R.P.D. (2015). Impacts of prescribed fire on soil loss and soil quality: An assessment based on an experimentally-burned catchment in central Portugal. Catena, 128: 278-293.

Sherman, L.A., Brye, K.R., Gill, D.E. and Koenig, K.A. (2005). Soil chemistry as affected by first-time prescribed burning of a grassland restoration on a coastal plain Ultisol. Soil Science, 170(11): 913-927.

Srivastava, P. and Garg, A. (2013). Forest fires in India: Regional and temporal analysis. Journal of Tropical Forest Science, 25(2): 228-239.

Terefe, W.T., Mariscal, S.I., Gómez, M.V. and Espejo, S.R. (2008). Relationship between soil colour and temperature in the surface horizon of Mediterranean soils: a laboratory study. Soil Science, 170: 495-503.

Tufeccioglu, A., Kucuk, M., Bilgili, E., et al., (2010). Soil properties and root biomass responses to prescribed burning in young corsican pine (Pinus nigra Arn.) stands. Journal of Environmental Biology, 31: 369-373.

Úbeda, X., Lorca, M., Outeiro, L., Bernia, S. and Castellnou, M. (2005). Effects of prescribed fire on soil quality in Mediterranean grassland (Prades Mountains, northeast Spain). International Journal of Wildland Fire, 14: 379-384.

Uggla, E. (1958). Ecological effects of fire on north Swedish forests. Almqvist and Wiksells Boktryckeri Ab, Uppsala.

Ulery, A.L., Graham, R.C., Chadwick, O.A. and Wood, H.B. (1995). Decade scale changes of soil carbon, nitrogen and exchangeable cations under chaparral and pine. Geoderma, 65: 121-134.

Verma, S. and Jayakumar, S. (2012). Impacts of forest fires on physical, chemical and biological properties of soil. A review. Proceedings of the International Academy of Ecology and Environmental Sciences, 2(3): 168-176.

Zavala, L.M., Granged, A.P., Jordán, A. and Bárcenas-Moreno, G. (2010). Effect of burning temperature on water repellency and aggregate stability in forest soils under laboratory conditions. Geoderma, 158: 366-374.

Received: 04 ${ }^{\text {th }}$ Jule 2020; Accepted: 19th December 2020;

First distribution: 07th January 2021. 